\title{
Dyplomacja Bruno Kreisky'ego wobec przemian na obszarze Europy Środkowej
}

\begin{abstract}
Bruno Kreisky and his diplomacy towards changes in Central Europe

Austria's political and economic interest in the countries of Central Europe was diverse. Neighborhood policy was interpreted as „a small relaxation that without direct union with the USSR could have contributed to relaxation between East and West". In initiating economic cooperation, it was assumed that the economic stability of Eastern countries would be conducive to the implementation of the basic task of the SPO, which is maintaining full employment, would be an optical expression of Austria's neutrality and would contribute to alleviating the effects of Austria's unilateral economic links with Western countries, in particular with Germany. The assumption adopted in Vienna concerned the consent to undertake economic cooperation where it was profitable, but also while respecting the principles typical of the free market. At the beginning it was assumed that industrialization concerns only East Germany and Czechoslovakia. Over time, this approach has changed. Analyzing the foreign policy of Austria, research tools characteristic of the historian and political scientist's workshop were used. The method of analysis and synthesis was adopted. Additionally, the conducted research was supplemented with the institutional method (legal acts regarding the competence to create foreign policy and state treaties). A statistical method was also used to show the scale of trade.
\end{abstract}

Keywords: modern Austria, neighborhood policy, Bruno Kreisky, Central Europe Słowa kluczowe: współczesna Austria, polityka sąsiedztwa, Bruno Kreisky, Europa Środkowa

\section{Wprowadzenie}

Zasadniczym celem naukowym niniejszej analizy jest badanie założeń i aktywności austriackiego polityka Bruno Kreisky'ego wobec przemian w Europie Środkowej. Ten wywodzący się z SPÖ minister spraw zagranicznych, lider partii socjalistycznej, a ostatecznie także wieloletni kanclerz II Republiki uznawał Wiedeń za centrum nowej powojennej Europy. Niezależna polityka wschodnia, jaką prowadził, trzymając się zasady wieczystej neutralności Austrii, stwarzała

*Doktor habilitowana, adiunkt na Wydziale Studiów Międzynarodowych i Politologicznych Uniwersytetu Łódzkiego, historyk zajmująca się relacjami polsko-austriackimi i historią dyplomacji; e-mail: agnieszka.kisztelinska@uni.lodz.pl. 
nowe możliwości polityczne dla takich państw jak Polska, dotychczas pozostających na uboczu polityki międzynarodowej. Dzięki Polsce Kreisky zmieniał swoje podejście do innych krajów Europy Środkowej. Uważał, że Warszawa dawała właściwy impuls do rozwoju całego regionu, podejmowała niezależne, dostosowane do swoich możliwości politycznych i decyzyjnych, plany dotyczące bezpieczeństwa w Europie, nieprzerwanie dążyła do zmian w obrębie reguł narzuconych przez Moskwę, ale w poczuciu budowy własnego państwa. Dużą rolę przypisywano w tym zakresie ludziom kultury i nauki. We wspomnieniach kanclerz podkreślał, że środowisko naukowe miało możliwości inicjowania zmian w kierunku ewolucji systemu politycznego. Zwracał także uwagę na potrzebę stwarzania przez państwa demokratyczne warunków do możliwości prezentacji osiągnięć państw wschodnich ${ }^{1}$. W kontekście dyplomacji austriackiej ważne pozostaje także pytanie o to, czy i w jakim stopniu kraje środkowoeuropejskie określały swoją wspólną tożsamość, ponieważ dotyczy to pewnej wspólnej reakcji na politykę, jaką zaproponował austriacki minister, a później kanclerz - Bruno Kreisky, wobec tego regionu².

Badania dotyczące genezy polityki Austrii wobec krajów komunistycznych zostały podjęte w połowie lat 90 . XX wieku. Jak piszą Peter Ruggenthaler i Maximilian Graf:

Od wielu lat temat polityki wschodniej Wiednia opisywano jedynie przy okazji innych wątków polityki zagranicznej. Trudno mówić w tym przypadku o przekrojowych badaniach odnoszących się do całego obszaru Europy Środkowej i długiego okresu powojennego. W kilku publikacjach podjęto solidne studia na temat stosunków dwustronnych Austrii, ZSRR i NRD, ale dotyczą one głównie lat 60 . XX wieku33.

Następująca analiza zakłada ukazanie dwóch zjawisk dotyczących tematu kształtowania ładu gospodarczego w Europie Środkowej. Pierwszym jest formułowanie celów współpracy gospodarczej przez Austrię, reprezentowaną

${ }^{1}$ B. Koszel, Mitteleuropa rediviva? Europa Środkowa i Potudniowo-Wschodnia w polityce zjednoczonych Niemiec, Poznań 1999, s. 15. Definiowanie zasięgu politycznego i kulturowego Europy Środkowej było niezwykle trudne. Jak pisze Weronika Parafianowicz-Vertun: „U źródeł różnego rodzaju kłopotów i kontrowersji związanych z pojęciem Europy Środkowej mógł leżeć jego geograficzny rodowód. Przekonanie, że przedmiotem środkowoeuropejskich dyskusji jest - historyczna, polityczna, kulturowa rzeczywistość tego regionu, prowadziło do konsternacji, kiedy okazywało się, że tworzone w dyskusjach obrazy nie przystają do środkowoeuropejskich realiów. W. Parafianowicz-Vertun, Europa Środkowa w tekstach i działaniach. Polskie i czeskie dyskusje, Warszawa 2016, s. 17-18.

${ }^{2}$ A. Kisztelińska-Węgrzyńska, Bruno Kreisky. Polityka zagraniczna i dyplomacja wobec PRL (1959-1983), Łódź 2018, s. 180-184.

${ }^{3}$ M. Graf, P. Ruggenthaler, Polnisch-österreichische Beziehungen im Kalten Krieg, [w:] Austria w polskim dyskursie publicznym po 1945 roku. Österreich nach 1945 im polnischen öffentlichen Diskurs, red. A. Kisztelińska-Węgrzyńska, Kraków 2016, s. 32-33. 
przez Bruno Kreisky'ego, wobec państw wschodnich, drugim - wartość ekonomiczna i społeczna wymiany handlowej na tym obszarze.

Omawiając politykę zagraniczną Austrii, wykorzystano narzędzia badawcze charakterystyczne dla warsztatu historyka i politologa. Przyjęto metodę analizy i syntezy. Dodatkowo uzupełniono prowadzone badania o metodę instytucjonalno-prawną (akty prawne dotyczące kompetencji kreowania polityki zagranicznej i traktaty państwowe). Wykorzystano też metodę statystyczną dotyczącą ukazania skali wymiany handlowej.

\section{Partnerzy na Wschodzie i recepcja dyplomacji Bruno Kreisky'ego}

W roku 1950 Kreisky został wezwany do Wiednia, aby objąć funkcję doradcy do spraw polityki zagranicznej przy urzędzie prezydenckim. W latach 1951-1959 sprawował wiele funkcji doradczych, dotyczących głównie polityki zagranicznej państwa, prac nad traktatem państwowym i umów handlowych zawieranych po II wojnie ${ }^{4}$. Był to czas, kiedy przeistoczył się on z doradcy politycznego i urzędnika niższej klasy w aparacie biurokratycznym państwa w czołowego polityka opozycyjnego, któremu powierzono kluczowy resort - Ministerstwo Spraw Zagranicznych. Kreisky, pełniący w młodym wieku funkcję ministra spraw zagranicznych, a od 1970 roku kanclerza, był wielokrotnie przywoływany w dyskursie państw komunistycznych jako gwarant dobrych stosunków ze Wschodem. Opisywano go przede wszystkim jako zdolnego socjalistę, mającego ambicje przywódcze, nie tylko w Austrii, ale także na forum międzynarodowym. Oceniano jako człowieka bardzo zamożnego i świetnie wykształconego, a w latach 70. nie obawiano się używać w odniesieniu do Kreisky'ego sformułowania - intelektualista. Najczęściej stosowaną strategią podczas prezentacji sylwetki kanclerza były metafory i cytaty pochodzące $z$ jego wypowiedzi. W świetle tych fragmentów ukazuje się człowiek dowcipny, oczytany, z dumą mówiący o swojej ojczyźnie i odważnie broniący jej interesów $w^{5}$. Wielokrotnie w tym czasie zderzano postać kanclerza $\mathrm{z}$ innymi zachodnimi politykami socjaldemokratycznymi. Podkreślając rolę i zasługi Kreisky'ego, wymieniano jego związki ze Wschodem6.

${ }^{4}$ Kanclerz Austrii Bruno Kreisky przybędzie do Polski, „Głos Robotniczy” 1973, nr 147, s. 1; M. Podkowiński, Neutralność $i$ wspótistnienie, „Perspektywy” 1973, nr 25, s. 26.

${ }^{5}$ Archiwum Ministerstwa Spraw Zagranicznych [dalej: AMSZ] D. IV: Austria, z. 31/82, w. 4, Tezy do rozmów Towarzysza Premiera P. Jaroszewicza z Kanclerzem Austrii, Bruno Kreiskym podczas nieoficjalnej wizyty w Polsce w dniach 16-20 września 1976 roku; ibidem, z. 47/77, w. 7, Pilna notatka z 10 maja 1973 roku.

${ }^{6}$ M. Podkowiński, Stanowczy kanclerz, „Perspektywy” 1975, nr 6, s. 8; idem, Obiad w Hofburgu [przed wizyta prezydenta Austrii w Polsce], „Perspektywy” 1975, nr 20, s. 9; B. Kreisky, Dwudziestolecie traktatu państwowego, „Austria-Polska. Czasopismo Gospodarczo-Społeczne” 1975, nr 94, s. 1; J. Urbaniak, Austriacy oczekuja szefa polskiego rzqdu, „Trybuna Ludu” 1965, nr 260, s. 1. 
W 1970 roku Kreisky, jako niekwestionowany lider socjalistów, po wygranych wyborach parlamentarnych został kanclerzem i funkcję tę sprawował nieprzerwanie do $1983 \mathrm{roku}^{7}$. Polityka sąsiedztwa, jaką realizował w trakcie swych rządów, miała różną dynamikę i priorytety. Nachbarschaftspolitik, czyli polityka sąsiedztwa, nabrała większego tempa ze względu na odprężenie w relacjach międzynarodowych, stąd liczba wizyt państwowych i zawieranych $\mathrm{w}$ tym czasie umów międzynarodowych wzrosła ${ }^{8}$. Dotychczasowe relacje Wiednia ze Wschodem oceniano pozytywnie: „Tym dobitniej podkreślić należy, że realista polityczny Kreisky stosuje w dziedzinie polityki zagranicznej taktykę popierania - czy raczej demonstracyjnego aprobowania - trendów rozwojowych, a więc trendu odprężeniowego czy idei zwołania EKBiW [Europejska Konferencji Bezpieczeństwa i Współpracy w Europie - A.K.W.]”9. Zdaniem Austriaków, odkładanie współpracy z obszarem wschodnim oznaczałoby zahamowanie procesu odprężenia na czas niedający się bliżej określić. „Polityka wschodnia dotyczy nas wszystkich" - twierdził Kreisky ${ }^{10}$.

Wśród krytycznych uwag pojawiały się także akcenty innej treści:

Obecnie Austria, obserwując szybko postępujący dialog Wschód-Zachód, usiłuje nadrobić własne zaległości, zwłaszcza że jej położenie geograficzne: sąsiedztwo z CSRS, Węgrami i Jugosławią, preferuje ją wręcz do odegrania ważnej funkcji w ramach procesu odprężenia i intensyfikacji stosunków Wschód-Zachód ${ }^{11}$.

Natomiast dokumenty archiwalne wskazują, że pierwsze szczegółowe interpretacje polityki austriackiej wobec państw wschodnich pochodziły z przełomu lat 50. i 60. Zaznaczono w nich potrzebę większego zainteresowania proponowaną współpracą, kierowaną, jak wówczas sądzono, wyłącznie do Jugosławii i Polski.

Zmiana w opisie i prezentacji sylwetki austriackiego polityka nastąpiła po $1973 \mathrm{roku}^{12}$. Nałożyły się na to nie tylko zmiany polityczne w Polsce, swoboda w wyrażaniu opinii, udział polskich korespondentów w wydarzeniach w samej Austrii, ale również bardzo pozytywny stosunek nowego kanclerza do Polski i zmian w okresie détente ${ }^{13}$. Kanclerz Kreisky uznał NRD, zorganizował serię wizyt w krajach demokracji ludowej, namawiał do podpisania wieloletnich umów

${ }^{7}$ B. Kreisky, Przemówienie [podczas spotkania w pałacu Rady Ministrów 25 VI 1973 roku], „Trybuna Ludu” 1973, nr 176, s. 4; idem, Przemówienie 30.09.1974, „Trybuna Ludu” 1974, nr 274, s. 2.

${ }^{8}$ AMSZ D. IV: Austria, z. 46/84, w. 2, Planowanie wizyty Bruno Kreisky'ego w Polsce; A. Kisztelińska-Węgrzyńska, Z historii dyplomacji polsko-austriackiej w latach 70. XX w. Wizyty kanclerza Austrii Bruno Kreisky'ego, „Przegląd Zachodni” 2015, nr 1, s. 139-157.

${ }^{9}$ AMSZ D. IV: Austria, z. 46/84, w. 2, Planowanie wizyty Bruno Kreisky'ego w Polsce.

${ }^{10}$ Ibidem, z. 47/77, w. 7, Notatka biograficzna 1973, s. 3.

${ }^{11}$ Ibidem, z. 47/77, w. 7, Pilna notatka z 9 lipca 1973 roku.

${ }^{12}$ R. Drecki, Austria: czynny udziat w sprawach Europy, „Trybuna Ludu” 1973, nr 113, s. 7.

${ }^{13}$ M. Podkowiński, Kreisky - fenomen czy symbol..., s. 124. 
gospodarczych, opartych na wymianie surowców i technologii. "Jest to niewątpliwy cios zadany polityce zjednoczeniowej RFN" - pisał Marian Podkowiński ${ }^{14}$.

Kreisky prowadził śmiałą politykę międzynarodową, prezentował się jako lider państw małych i niezaangażowanych podczas szczytu Konferencji Bezpieczeństwa i Współpracy w Europie (KBWE), a także optował za stworzeniem silnej kolacji państw zaangażowanych $\mathrm{w}$ rozbrojenie ${ }^{15}$. W ocenie reform zrealizowanych przez pierwsze dwa gabinety Kreisky'ego dominowały pochwały. Każde kolejne wygrane wybory $(1975,1979)$ opisywano w kontekście jego wielkiego osobistego sukcesu politycznego. Przybliżano reformy, jakie zapewniły mu zwycięstwo i relacjonowano kompromisy zawierane pomiędzy socjalistycznym rządem i poszczególnymi grupami społecznymi ${ }^{16}$. Wiele uwagi poświęcono chociażby referendum na temat wykorzystania energii pochodzącej $\mathrm{z}$ elektrowni atomowych.

U schyłku lat 70. pisano o Kreiskym jako o fenomenie. Na dalszy plan zeszły zarzuty o antykomunizm, choć nie znaczy to, aby o nich zapomniano. Podkreślano dumę Austriaków z silnego kanclerza, który wzmocnił ich kraj i stworzył z Wiednia centrum międzynarodowej dyplomacji ${ }^{17}$. Choć gospodarka austriacka w dużym stopniu związana była z zachodnioniemiecką, to przez wahania koniunkturalne przeżywała rozkwit. Bezrobocie wynosiło $2 \%$ i było najniższe w Europie. Kreisky przewidział nadciągający na początku lat 70. kryzys energetyczny i odpowiednio przygotował na niego Austrię. Polscy publicyści, opisując politykę bliskowschodnią Wiednia, zwracali uwagę na niezależność tego państwa i konieczność silniejszej z nim kooperacji ekonomicznej ${ }^{18}$.

$\mathrm{W}$ strategiach narracyjnych $\mathrm{w}$ drugiej połowie lat 70 ., aż do ustąpienia kanclerza w 1983 roku, zwraca się uwagę na fakt posiadania przez Wiedeń i Warszawę wspólnego wroga, jakim były Niemcy Zachodnie ${ }^{19}$. Wielokrotnie podkreślano te wydarzenia z życia politycznego Austrii, które wskazywały na konflikt interesów z Bonn. $Z$ drugiej zaś strony próbowano tłumaczyć opinii publicznej, że Kreisky był pośrednikiem w relacjach z Niemcami, ponieważ cieszył się dużym poparciem wśród tamtejszych socjaldemokratów. Wątek współpracy z Europą Środkową po II wojnie światowej, w nowych warunkach politycznych stanowił ważny element polityki zagranicznej zarówno RFN,

${ }^{14}$ Cyt. za ibidem.

${ }^{15}$ AMSZ D. IV: Austria, z. 43/84, w. 5, Informacja o wynikach wizyty Prezesa Rady Ministrów Towarzysza Edwarda Babiucha w Austrii.

${ }^{16}$ J. Tycner, Ery Kreisky'ego ciag dalszy, „Prawo i Życie” 1979, nr 21, s. 13.

${ }^{17}$ T. Brodzic, Mosty i polityka, „Prawo i Życie” 1976, nr 46, s. 13.

${ }^{18}$ D. Luliński, Austria i polityka odprężenia. Korespondencja $z$ Wiednia, „Trybuna Ludu” 1979, nr 117, s. 7.

${ }^{19}$ B. Kreisky, Neutralność nie oznacza absencji w polityce międzynarodowej. Rozm. M. Podkowiński, „Perspektywy” 1972, nr 23, s. 67; Z. Ramotowski, Mat kanclerski. Austria po wyborach, „Życie Warszawy” 1975, nr 233, s. 5. 
jak i Austrii. Obydwa państwa musiały wyrazić swój stosunek do państw komunistycznych, uznając prymat polityczny Moskwy nad tą częścią Europy. Konieczność współpracy, zwłaszcza ekonomicznej, z tym obszarem zmuszała do przygotowania choćby doraźnych rozwiązań w tym zakresie.

W latach 80. o kanclerzu Kreiskym pisano właściwie w samych superlatywach, tworząc w ten sposób wizerunek nietuzinkowego polityka. Polskie materiały PAP czy archiwalia chwaliły zachodniego partnera za umiejętność przewidywania problemów politycznych i rozstrzygania ich na drodze skutecznych reform. Przekazy prasowe obfitowały w relacje $\mathrm{z}$ austriackiego życia politycznego, w których opisywano nie tylko udane decyzje polityczne, ale również nastroje społeczne i źródła popularności kanclerza ${ }^{20}$. Socjalistyczne poglądy były wówczas atutem. Kreisky'ego opisywano jako „swojego człowieka w Wiedniu" i w pewnym sensie utożsamiano się z jego sukcesami. Po wprowadzeniu stanu wojennego kanclerz wycofał się z dialogu z polską władzą. Odmówił spotkania, oficjalnej pomocy i zaangażował się w akcje społeczne, wspierające polskich obywateli w zakresie pomocy materialnej czy łączenia rodzin. Strona polska do 1989 roku w oficjalnych komunikatach oceniała Austrię jako wyjątkowego partnera politycznego i gospodarczego ${ }^{21}$.

Komentując realizację polityki sąsiedztywa, dyplomaci podkreślali:

Kreisky jest politykiem zdecydowanie prozachodnim, elastycznie i zręcznie reagującym na wydarzenia w polityce międzynarodowej. Przy całym swoim „programowym” antykomunizmie i selektywnym podejściu do KS-ów [krajów socjalistycznych - A.K.W.] ma jednak ambicje odgrywania roli europejskiego męża stanu, zwłaszcza w dziedzinie normalizacji międzypaństwowych stosunków europejskich, stawiającego na utrzymanie pozycji Austrii jako aktywnego partnera europejskiego dialogu i znajdowanie koncyliacyjnych rozwiązań. Posiada zdolność wyczuwania nastroju społeczeństwa, w zależności od potrzeb potrafi w sposób oportunistyczny zlekceważyć wszelkie skrępowania oraz nakazy partyjne i ideologiczne. Posiada duże poczucie humoru. Ataki przeciwników odpiera często przy pomocy celnego, niszczącego dowcipu. Posiada umiejętność taktycznego wykorzystania błędów przeciwników. Jest zawsze gotowy do dyskusji na każdy temat, w czasie której przejawia dużą aktywność, wojowniczość i ducha walki ${ }^{22}$.

${ }^{20}$ T. Derlatka, W obronie superbogatych, „Trybuna Ludu” 1977, nr 59, s. 6; J. Staribacher, Perspektywy wspótpracy gospodarczej z Polska, „Przegląd Organizacji” 1976, nr 10, s. 410.

${ }^{21}$ AMSZ D. IV: Austria, z. 8/86, w. 4, Notatka o ważniejszych aspektach stosunków polsko-austriackich; ibidem, z. 8/86, w. 4, Sugestie do rozmowy Towarzysza Ministra S. Olszowskiego $z$ austriackim ministrem Sz.W. Pahrem; ibidem, z. 8/86, w. 4, Sugestie do rozmów Tow. F. Wiejacza $w$ Wiedniu.

${ }^{22}$ Ibidem, z. 47/77, w. 7, Notatka biograficzna 1973, s. 5. 
W odniesieniu do wschodnioeuropejskich krajów satelickich Kreisky trzymał się zasadniczo jednej reguły: chodziło mu o to, by odbudować stosunki polityczne i wymianę handlową. Podczas gdy pojęcia takie, jak polityka sąsiedztwa czy polityka wschodnia kojarzyły się raczej z programem ogólnowschodnioeuropejskim, Kreisky traktował każde państwo na własny sposób ${ }^{23}$. Ocena całości relacji Austrii z państwami wschodnimi była tak samo trudna jak ryzykowna. Dyplomacja Kreisky'ego wobec Wschodu, początkowo opisywana ostrożnie, z czasem zyskała pozytywne akcenty ${ }^{24}$. Po pierwszych wygranych wyborach w 1970 roku zastanawiano się, na ile program wyborczy socjalistów był zdominowany przez obietnice i „piękne słówka”, czy rzeczywiście stanowił „alternatywę dla nowoczesnej Austrii”" ${ }^{25}$. Kanclerz jawił się jako partner, sojusznik, ambitny przywódca, lider socjalistów, polityk otwarty na Wschód i chętny do współpracy gospodarczej z tym obszarem ${ }^{26}$.

Austriacy charakteryzowali wówczas Europę Środkową jako pewien postulat polityczno-historyczny, czy też ideę ewoluującą z nostalgicznych przekonań o wspólnym dziedzictwie w stronę konkretnych działań, praktyk, rozwiązań politycznych. Wynikało to z możliwości, jakie istniały w samych państwach zaliczanych do obszaru wschodniego czy południowego Europy. Koncepcja Europy Środkowej jako obszaru „wspólnego”, posiadającego określone właściwości polityczne była tak samo chętnie zarówno promowana, jak i negowana. Publikowano też bardzo liczne teksty polemiczne, utrzymujące, że nie było niezrealizowanej koncepcji alternatywnej, ale tylko pewien mit, do którego łatwo było się odwołać dzięki powtarzalności przekazów dotyczących środkowoeuropejskiej rzeczywistości ${ }^{27}$.

Pytanie o to, czy i w jakim stopniu kraje środkowoeuropejskie określały swoją wspólną tożsamość dotyczy również tego, czy koncepcja polityki sąsiedztwa była odpowiedzią na procesy społeczne, jakie wówczas obserwowano, czy raczej iskrą, która je inicjowała. Należy wziąć pod uwagę, że obserwowano nie tylko potrzeby i możliwości podejmowane na poziomie państwowym, lecz sugerowano się potrzebami społecznymi i kulturalnymi rodzącymi się na Wschodzie ${ }^{28}$. Aktywizacja środowisk intelektualnych, wsparcie dla kultury,

${ }^{23}$ T. Bodulan, Z sympatii i wzajemnych korzyści, „Czas” 1976, nr 48, s. 21; M. Podkowiński, W strone odprężenia, „Perspektywy” 1976, nr 49, s. 18.

${ }^{24}$ J. Moszczeński, Trudna kadencja. Po sukcesie SPÖ, „Życie Warszawy” 1975, nr 280, s. 8.

${ }^{25}$ K.K. Sylwetka tygodnia, „Tygodnik Kulturalny” 1970, nr 13, s. 2.

${ }^{26}$ T. Derlatka, Obrady polsko-austriackiej komisji gospodarczej, „Trybuna Ludu” 1976, nr 228, s. 2; idem, Pod figowym listkiem niezależności, „Trybuna Ludu” 1977, $\mathrm{nr} 44$, s. 7; idem, Polsko-austriacka wspótpraca gospodarcza, „Życie Warszawy” 1976, nr 227, s. 4.

${ }^{27}$ Weronika Parafianowicz-Vertun analizuje te teksty na poziomie mikrostruktur i zwraca uwagę na ich powtarzalność, odwoływanie się do tych samych wydarzeń, cytatów, figur retorycznych, postaci. W. Parafianowicz-Vertun, op. cit., s. 14.

${ }^{28}$ J. Kurczewska, A.Z. Kamiński, Przemiany instytucjonalne w Polsce. Elita politycznych nomadów, [w:] Dezercja elit. Konsolidacja ustroju politycznego w pokomunistycznej Polsce, Warszawa 2014, s. $81-106$. 
a także wspólne inwestycje podnoszące poziom społeczny przeciętnych obywateli, to były rozwiązania, których wsparcie interesowało Kreisky'ego na równi z reprezentowaniem interesów Austrii na tym obszarze ${ }^{29}$.

\section{Cele polityki inwestycyjnej na obszarze Europy Środkowej}

Najważniejsza zasada, jaką przyjął Kreisky jeszcze w trakcie pracy nad traktatem państwowym, stanowiła, że nie odrzucano możliwości współpracy ze Wschodem. Od tego momentu niezależny austriacki resort spraw zagranicznych określił ramy prawne współpracy z państwami sąsiadującymi. Unikano sformułowań „Wschód”, nie kojarzono tego obszaru działań ani z definiowaną w historiografii niemieckiej Ostpolitik, ani też nie formułowano tez o współpracy z blokiem wschodnim. Nachbarschaftspolitik to szeroko pojęta polityka z państwami sąsiadującymi. $\mathrm{Z}$ ich udziałem gospodarka powojennej Austrii miała się swobodnie rozwijać.

Polityka wobec państw komunistycznych, realizowana początkowo głównie w wymiarze gospodarczym, interpretowana była jako „małe odprężenie, które bez bezpośredniego zjednoczenia z ZSRR mogło przyczynić się do odprężenia między Wschodem i Zachodem" ${ }^{30}$. Inicjatywy dotyczące kooperacji przemysłowej i współpracy gospodarczej realizowano, wychodząc z założenia, że stabilność gospodarcza krajów bloku wschodniego miała sprzyjać realizacji podstawowego zadania socjaldemokratów, jakim było utrzymanie pełnego zatrudnienia. Była ona także optycznym wyrazem neutralności Austrii i przyczyniła się do łagodzenia skutków jednostronnych powiązań ekonomicznych Austrii z państwami zachodnimi, w tym zwłaszcza z RFN ${ }^{31}$. Założenia przyjęte przez Kreisky'ego obejmowały zgodę na podjęcie współpracy ekonomicznej tam, gdzie było to opłacalne, ale także przy poszanowaniu zasad typowych dla wolnego rynku.

W odniesieniu do celów formułowanych wobec przyszłej współpracy gospodarczej Austriacy byli głównie zainteresowani rozbudową infrastruktury. Stawiano na reanimację starej arterii komunikacyjnej:

Gdyby udało się rozbudować Dunaj do trasy komunikacyjnej połączonej z Renem i dalej z Morzem Północnym oraz z Odrą i Morzem Bałtyckim, otworzyłoby to drzwi dla komunikacji i transportu towarów drogą morską nie tylko dla Austrii, lecz dla całej Środkowej i Wschodniej Europy. Dzięki temu wszystkie państwa nad Dunajem mogłyby doświadczyć rewolucyjnej przemiany ${ }^{32}$.

${ }^{29}$ A. Kisztelińska-Węgrzyńska, Bruno Kreisky..., s. 180-184.

${ }^{30}$ E. Röhrlich, Kreiskys Aussenpolitik. Zwischen österreichischer Identität und internationalen Programm, Zeitgeschichte im Kontext 2, Göttingen 2009, s. 247.

${ }^{31}$ AMSZ, D. IV: Austria, z. 1/84, w. 3, Podstawowe elementy dziatalności B. Kreisky'ego i roli Socjalistycznej Partii Austrii w Międzynarodówce Socjalistycznej.

${ }^{32}$ E. Röhrlich, op. cit., s. 250. 
W koncepcjach wschodniej i środkowej Europy Dunaj zajmował szczególne miejsce, wynikające zarówno z jego znaczenia gospodarczego, jak i z siły, którą symbolizował. Państwa nad Dunajem łączy wyjątkowe poczucie sąsiedztwa i wspólne położenie w głównej arterii komunikacyjnej Europy. Zwracano uwagę na wyraźne różnice pomiędzy pojedynczymi mniejszościami narodowymi w zagłębiu Dunaju. Ruchy narodowe istniały tam mimo sowieckich rządów. Przytaczano także historyczne cechy wspólne „w starej monarchii naddunajskiej” i fakt, że Austriacy dobrze znają różnice między pojedynczymi mniejszościami narodowymi na tym obszarze. „Musimy być świadomi, że my, Austriacy, możemy działać w Środkowej Europie tylko w sposób kreatywny". Uprzywilejowanej pozycji doszukiwano się raczej w geograficznym położeniu Austrii: „Chcemy w tej części kontynentu, w której przez długi czas byliśmy bierni, być odtąd gwarantem stabilizacji” ${ }^{33}$.

Na przełomie lat 50. i 60. XX wieku sformułowano koncepcję współpracy w ramach relacji dobrosąsiedzkich ze wszystkimi państwami otaczającymi Austrię, zwłaszcza zaś państwami wschodnimi ${ }^{34}$. Jak pisano, czyniono to w poczuciu dbałości o interesy Wiednia i pewnej potrzeby odpowiedzialności za rozwój innych państw, z którymi losy Austrii związane były od stuleci. Były to zarówno państwa sąsiadujące w sensie dosłownym, jak i przenośnym (do tych ostatnich należała Polska).

Problematyka związana z kształtowaniem polityki zagranicznej II Republiki i rolą polityki sąsiedztwa została gruntownie omówiona w pracach austriackich $^{35}$. Badania te dotyczą genezy samej koncepcji i koncentrują się głównie na ocenie współpracy z ZSRR i NRD. Powstało wiele prac ujmujących stosunki dwustronne Austrii z Czechosłowacją, Węgrami, Rumunią, Bułgarią, i Jugosławią, w których autorzy opisali warunki współpracy z szeroko pojętym Wschodem. Brakuje jednak badań szeroko ujmujących ogół relacji II Republiki Austrii z Europą Środkową ${ }^{36}$.

Europa Środkowa to w pewnym stopniu także kierunek rozwoju narzucony Austrii na mocy porozumień poprzedzających podpisanie traktatu państwowego,

${ }^{33}$ B. Kreisky, Politik braucht Visionen, Aufsatze, Reden und Interviews zu aktuellen weltpolitischen Fragen, Bonn 1982, s. 108.

${ }^{34}$ O. Höll, op. cit., s. 105.

${ }^{35}$ O. Rathkolb, Austria's „Ostpolitik” in the 1950s and 1960s., „Austrian History Yearbook” 1995 Vol. XXVI, s. 129-149; Der österreichische Staatsvertrag 1955. Internationale Strategie, rechtliche Relevanz, nationale Identität. The Austrian State Treaty. International Strategy, Legal Relevance, National Identity, eds A. Suppan, W. Mueller, G. Stourzh, Wien 2005; Austria's International Position after the End of the Cold War (Contemporary Austrian Studies, Vol. 22), eds G. Bischof, F. Karlhofer, New Orleans 2013.

${ }^{36}$ Za obszar Europy Środkowej przyjęto, za Oskarem Haleckim, te kraje, które leżąc we wschodniej części kontynentu, mają szczególnie bliskie kulturowe i polityczne związki z łacińskim Zachodem. O. Halecki, Historia Europy, jej granice i podziaty, Lublin 2000, s. 134; E. Röhrlich, op. cit., s. 127-151. 
o czym pisał austriacki historyk Olivier Rathkolb ${ }^{37}$. Okres okupacji Austrii na dziesięć lat zamroził rozmowy dotyczące choćby kwestii mniejszości narodowych czy spornych terytoriów. Przyszłość tych zagadnień rozstrzygały zapisy traktatu państwowego z 1955 roku. Do 1965 roku większość kontrowersyjnych spraw została rozstrzygnięta na rzecz polepszenia i dalszego rozwoju stosunków dwustronnych, głównie dzięki serii wizyt roboczych zwiastujących poprawę wymiany handlowej.

Inaczej niż sugerował zwrot „,blok wschodni”, kraje satelickie nie tworzyły monolitycznego bloku ${ }^{38}$. Zdaniem Kreisky'ego, pomijając te różnice, czyniono Związkowi Sowieckiemu przysługę, ponieważ Moskwa chciała zintegrować pojedyncze kraje w możliwie spójny blok. Policentryzm komunizmu, który uwidaczniał się $\mathrm{w}$ kontraście pomiędzy ZSRR i Chinami, wzmacniał proces dezintegracji w strefie wschodniej. Austriacki polityk uważał, że należy wykorzystać to zjawisko dla własnych celów ${ }^{39}$.

Początki polityki sąsiedztwa opierały się na współpracy z Jugosławią, Polską i Czechosłowacją, a w dalszej kolejności z pozostałymi sąsiadami o komunistycznych reżimach. Celem zasadniczym było skupienie współpracy na kontaktach bilateralnych, wspartych bezpośrednimi konsultacjami z przywódcami rosyjskimi, zwłaszcza Nikitą Chruszczowem. Pierwszym wyraźnym sukcesem było zainicjowanie spotkania Chruszczow-Kennedy w Wiedniu w 1961 roku. Olivier Rathkolb napisał, że polityka realizowana przez Kreisky'ego wobec państw wschodnich była „specyficzna”. W dużej mierze zależała od jego ambicji politycznych i osobistego nastawienia do Wschodu. Nie obawiał się on współpracować z komunistami, a z drugiej strony - jego aktywność była wypadkową tendencji w rządzie Juluisa Raaba wobec integracji z Europą Zachodnią. Kreisky odrzucał ten model rozwoju jako jedyny, uważał, że poszukiwanie alternatywy przyniesie więcej korzyści Austrii, dlatego dążył m.in. do zacieśnienia relacji z państwami neutralnymi i współpracy w ramach EFTA (European Free Trade Association - Europejskie Stowarzyszenie Wolnego Handlu). Był za to wielokrotnie krytykowany przez Amerykanów. Z jednej strony, postrzegali go jako polityka zdecydowanie prozachodniego i antykomunistycznego, z drugiej zaś, specyficzna niesubordynacja i „trzymanie Austrii z dala” od wspólnego rozwoju Europy Zachodniej narażało II Republikę na krytykę. Nie dostrzegano w dyplomacji Kreisky'ego specyficznego poczucia patrio-

${ }^{37}$ W. Parafianowicz-Vertun, op. cit., s. 17-18; Ch. Maier, Whose Mitteleuropa. Central Europa between Memory and Obsolescence, „Austrian in the New Europe. Contemporary Austrian Studies" 1993, Vol. 1, s. 8-19.

${ }^{38}$ O. Rathkolb, „Europa mit der Seele suchen”. Bruno Kreiskys andere Europa-Visionen, [w:] Bruno Kreisky. Seine Zeit und mehr. Era and Aftermath. Wissenschaftliche Begleitpublikation zur 240. Sonderausstellung des Historichen Museums der Stadt Wien 18. September bis 15. November 1998, Wien 1998, s. 87-105.

${ }^{39}$ E. Röhrlich, op. cit., s. 246. 
tyzmu, zarówno w doborze celów, jak i metod realizacji przyjętych zadań. Socjalistyczny minister wielokrotnie powtarzał wówczas, że najważniejszy jest interes narodowy państwa, nie zaś związki ponadnarodowe, bez względu na to, jakie systemy polityczne reprezentują ${ }^{40}$.

Lata 60 . były trudnym okresem w relacjach polsko-austriackich. Impas wynikał z kierowania polskiej aktywności politycznej na sprawę uznania granicy zachodniej Polski, co spychało inne kierunki działań na dalszy plan. Dostrzegano, co prawda, pozytywne efekty realizacji umów handlowych i zabiegano o umocnienie wymiany gospodarczej z Austrią, lecz zarówno wymiana przedstawicieli politycznych, jak i plany rozwoju stosunków dwustronnych do połowy dekady pozostawały bez widocznych zmian. Doceniano osobistą dyplomację ministra Kreisky'ego i jego udane relacje z państwami bratnimi, lecz koncentrowano się na perspektywie współpracy z Bonn ${ }^{41}$.

$\mathrm{W}$ latach 60. Austria realizowała politykę sąsiedztwa w oparciu o wizyty w państwach wschodnich, w trakcie których podpisywano umowy gospodarcze. Dzięki tym spotkaniom zachodni politycy zapoznawali się z realiami politycznymi, w jakich żyli sąsiedzi, z możliwościami, jakie posiadali przywódcy państw komunistycznych, czy warunkami współpracy gospodarczej ${ }^{42}$. Według badaczy austriackich polityka wizyt państwowych - Besuchsdiplomatie była podstawą rozwoju poprawnych relacji dwustronnych. Rewizyty były znacznie rzadziej praktykowane. Zależało to nie tylko od nastawienia państw wschodnich, ale też od warunków politycznych, w jakich w tym czasie się znajdowały ${ }^{43}$.

Programowe mowy dotyczące polityki sąsiedztwa socjalistyczny minister wygłosił w Bukareszcie (1963), Budapeszcie (1964) i Sofii (1965), ale od początku lat 60. o sytuacji w Europie Środkowej mówił coraz częściej także w państwach sojuszu zachodniego, do których podróżował częściej. Wyznacznikiem zadań politycznych dla dyplomacji polskiej w połowie lat 60 . XX wieku była zmiana na najwyższych szczeblach władzy w ZSRR. W 1964 roku od władzy

\footnotetext{
${ }^{40}$ M. Graf, P. Ruggenthaler, op. cit., s. 33. Badania dotyczące genezy polityki wschodniej Austrii zostały podjęte w połowie lat 90 . XX wieku.

${ }^{41}$ W. Jarząbek, Polska Rzeczpospolita Ludowa wobec polityki wschodniej Republiki Federalnej Niemiec w latach 1966-1976. Wymiar dwustronny i międzynarodowy, Warszawa 2011, s. 396-413.

${ }^{42}$ Jesienią 1965 roku Kreisky wygłosił na uniwersytecie w Yale długi wykład „Zmiany w rejonie Dunaju”. Mówił o najnowszych politycznych projektach w tym obszarze. Z okazji wizyty ministra spraw zagranicznych zorganizowano w USA tydzień kultury austriackiej, który odbywał się od 17 do 30 października w Dallas. Na jego otwarcie Kreisky poleciał do Teksasu razem z przewodniczącym Rady Federalnej Rudolfem Salligerem (ÖVP). Wskazywał wówczas wyraźnie na różnice pomiędzy pojedynczymi mniejszościami narodowymi w zagłębiu Dunaju. Ruchy narodowe istniały tu mimo sowieckiego panowania. Austria, jako jedyne niekomunistyczne państwo w regionie, ponosiła w tej części Europy specjalną odpowiedzialność. O. Rathkolb, Austria’s „Ostpolitik”..., s. 143.

${ }^{43} \mathrm{O}$. Höll, The Politics of Global Thinking. The International Significance of Bruno Kreisky, [w:] Bruno Kreisky. Seine Zeit und mehr..., s. 105-117.
} 
został odsunięty Nikita Chruszczow i tuż po tych burzliwych zmianach polska delegacja państwowa udała się na spotkanie z nowym przywódcą sowieckim Leonidem Breżniewem ${ }^{44}$. Efektem spotkania w listopadzie 1964 roku w Moskwie było m.in. przyjęcie zasad „aktywizacji politycznej na linii z Zachodem”, co sugerowano w Moskwie, a efektów czego spodziewano się na całym obszarze wschodnim ${ }^{45}$. Zdaniem polskich badaczy, tendencja do aktywnej polityki zagranicznej, zwłaszcza z państwami neutralnymi, istniała już od 1956 roku i wynikała z przymusu ekonomicznego, a także z próby ograniczenia wydatków na zbrojenia ponoszonych przez obydwa bloki państw ${ }^{46}$. Koncepcje współpracy z krajami wschodnimi ewoluowały wraz z rozwojem sytuacji politycznej w poszczególnych państwach. Konsekwencje wynikające z II wojny światowej, oczekiwania gospodarcze i ambicje polityków komunistycznych tworzyły mozaikę zależności, w której wspólnym mianownikiem były ramy reżimu komunistycznego.

Polskie władze nie analizowały uwarunkowań polityki sąsiedztwa. Znacznie większą uwagę przywiązywano do relacji austriacko-niemieckich czy konfliktów granicznych ${ }^{47}$. Pisząc o polityce austriackiej wobec obszaru wschodniego, zwracano uwagę na zbieżność z koncepcjami Willy'ego Brandta, podkreślając bliską zażyłość socjalistycznych polityków i wspólne doświadczenia emigracyjne $^{48}$. Jeśli już oceniano austriacką dyplomację wobec Wschodu, to raczej doszukiwano się w niej resentymentów z czasów monarchii austro-węgierskiej czy wspólnej przeszłości ${ }^{49}$.

Recepcja rozwoju wymiany gospodarczej pomiędzy krajami wschodnimi i Austrią była powściągliwa ${ }^{50}$. Politykę Wiednia traktowano jako próbę przeciwstawienia się gospodarczym wpływom Niemiec w Europie. Natomiast kryzysy polityczne rozgrywające się wewnątrz państw komunistycznych jedynie częściowo osłabiały wymianę ekonomiczną z Zachodem. Inwazja wojsk Ukła-

${ }^{44}$ P. Madajczyk, Dyplomacja polska w latach sześćdziesiątych, [w:] Historia dyplomacji polskiej, t. VI: 1944/1945-1989, red. W. Materski, W. Michowicz, Warszawa 2010, s. 584-654.

${ }^{45}$ Normy prawne przyszłej współpracy zapisano w Układzie o przyjaźni, współpracy i wzajemnej pomocy, zawartym między PRL i ZSRR w Warszawie 8 kwietnia 1965 roku. Polska w stosunkach międzynarodowych 1945-1989. Wybór dokumentów, red. J. Zając, Warszawa 2005, s. 88-91.

${ }^{46}$ A. Skrzypek, Dyplomatyczne dzieje PRL w latach 1956-1989, Warszawa 2010, s. 116-117.

${ }^{47}$ Szczegółową ocenę wymiany handlowej do roku 1973 przedstawiono w: J. Sikorski, Przyszłość polsko-austriackich stosunków gospodarczych, „Sprawy Międzynarodowe” 1973, nr 9, s. 104-113; J. Stairbacher, Austriacko-polskie stosunki gospodarcze, „Austria-Polska. Czasopismo Społeczno-Kulturalne" 1973, s. 13.

${ }^{48}$ W. Brandt, B. Kreisky, O. Palme, Briefe und Geschpräche. 1972-1975, Frankfurt am Main (rec. R. Kumf), „Problemy Pokoju i Socjalizmu” 1980, nr 2, s. 145-149.

${ }^{49}$ A. Kosowski, Wspótpraca gospodarcza państw Dunaju, „Świat i Polska” 1947, nr 18, s. 3.

${ }^{50}$ A. Kisztelińska-Węgrzyńska, Österreich in der polnischen Diplomatie in den Jahren 19651968 aus der Perspektive des Aussenministeriums der VR Polen, „International Studies. Interdisciplinary Political and Cultural Journal (Österreich in der gegenwärtigen polnischen Forschung)" 2016, Vol. 18, No. 1, s. 33-52. 
du Warszawskiego na Czechosłowację zmieniła tylko w pewnym stopniu relacje dwustronne. Austria była dla uciekinierów z Czechosłowacji przystankiem w drodze na Zachód, jak również przystankiem w drodze do Czech, dokąd duża część migrantów wróciła. W związku z tym, że władze czeskie chętnie pozbywały się przeciwników władzy komunistycznej, austriackie obozy bardzo szybko się przepełniły. Potrzeba pomocy humanitarnej zachęciła polityków austriackich do większej pomocy dla Czechosłowacji, jednak w Wiedniu obawiano się podsycać dotychczasowe antagonizmy czesko-słowackie ${ }^{51}$. Zdaniem Davida Schriffla, historyka badającego powojenne relacje austriacko-słowackie, Praska Wiosna nie zaszkodziła wzajemnym relacjom gospodarczym tak bardzo, jak przejęcie po 1945 roku własności austriackiej w Czechosłowacji. Poza tym największym problemem w tych relacjach były kolektywizacja i brak wsparcia dla przedsiębiorczości ${ }^{52}$.

U schyłku lat 60. niemiecka polityka wschodnia przyniosła pierwsze efekty wymiany z państwami zza żelaznej kurtyny na wzór dyplomacji austriackiej. Polityka współpracy z państwami wschodnimi, zainicjowana przez wielką koalicję CDU-CSU i SPD, kontynuowana przez SPD po 1969 roku, została porównana przez austriackiego historyka Olivera Rathkolba do podobnych działań realizowanych przez Wiedeń od początku lat 60 . Badacz ten stwierdził, że zarówno niemieckie, jak i austriackie działania w ramach współpracy ze Wschodem były inspirowane przez władze amerykańskie i wyprzedziły okres odprężenia znany w literaturze jako détente ${ }^{53}$.

Zdaniem Austriaków, wyzwaniem tamtych czasów było przekształcenie „rynków sprzedawcy” w „rynki kupującego”. Efektem zmian było stworzenie stosunków multilateralnych opartych na ułatwieniach płatniczych i celnych, a co za tym idzie, stworzenie wspólnych organizacji tych państw. Integracja gospodarcza w postaci Europejskiej Wspólnoty Gospodarczej (EWG) zakładała utworzenie „ponadpaństwowej wspólnoty”. Austria nie przystąpiła do wspólnoty państw zachodnich, choć łączyły ją z tym obszarem ponadpięćdziesięcioprocentowe obroty handlowe. Była to cena, jaką zdecydowała się ponieść, zachowując neutralność. W ramach alternatywy wybrano porozumienie EFTA, z państwami której obroty sięgały $13 \%$. Według austriackiego ministra dyskusja nad przyszłością integracji Austrii z EWG i EFTA nie została zakończona i stanowiła istotny problem międzynarodowy.

Austriackie MSZ stało na stanowisku, że w ówczesnej sytuacji politycznej niemożliwe było zmniejszenie dostaw surowcowych ze strony Niemiec czy Włoch po to, by zwiększyć dostawy z Polski. Zwrócono również uwagę na austriackie wskaźniki gospodarcze, w świetle których handel z Anglią wypadał gorzej

${ }^{51}$ H. Fischer, op. cit., s. 228.

${ }^{52}$ D. Schriffl, Tote Grenze oder lebendige Nachbarschaft? Österreichisch-slowakische Beziehungen 1945-1968, Wien 2012.

${ }^{53}$ M. Graf, P. Ruggenthaler, op. cit., s. 32-33. 
niż z Polską. Widziano potencjalne możliwości zwiększenia importu innych towarów, ale pozostałe państwa RWPG (Rada Wzajemnej Pomocy Gospodarczej) stanowiły dla Polski widoczną konkurencję. Odnosząc się do współpracy gospodarczej z państwami trzecimi, zwrócono uwagę na konieczność zaproszenia do Polski delegacji jugosłowiańskiej, z którą Wiedeń miał pozytywne doświadczenia ${ }^{54}$. Przychylnie oceniono również możliwość wykorzystania polskich portów do współpracy z państwami skandynawskimi. Uzależniono ją jedynie od konkurencyjności polskich jednostek frachtowych. Niezwykle ciepło przyjęto propozycję budowy kanału Odra-Dunaj. Kreisky obiecał w tej sprawie natychmiastową interwencję na forum Europejskiej Komisji Gospodarczej w Genewie. Koncepcja ta była systematycznie planowana od 1961 roku, kiedy podczas spotkania ministrów Kreisky'go i Rapackiego przyznano, że inwestycja była korzystna dla wielu państw. W tym czasie próbowano włączyć do tego projektu, bez powodzenia, stronę czechosłowacką ${ }^{55}$. Kreisky rozważał również współpracę w tym zakresie z NRD, choć bardziej liczył na to, że strona polska będzie w stanie zainteresować Berlin taką inwestycją ${ }^{56}$.

Do najtrudniejszych relacji w polityce sąsiedztwa należały stosunki Wiednia z Pragą. Podczas gdy pierwsze bilateralne negocjacje dotyczące umów gospodarczych prowadzone były już na przełomie lat 1945/1946, klimat międzypaństwowy pogorszył się już w 1946 roku. Największe nieporozumienia wynikały z pertraktacji na temat spraw majątkowych. Dopiero z końcem 1974 roku doszło do porozumienia w kwestii austriackiej własności. Również stosunek do Węgier kształtował się z pewnymi komplikacjami, a krwawe stłumienie rewolucji z 1956 roku skutkowało też w latach późniejszych. Austria zajęła tu ideologicznie i humanitarnie jasne stanowisko, przyjmując węgierskich uchodźców. Odtąd na zaminowanej granicy nieustannie dochodziło do incydentów. W 1964 roku Kreisky, jako pierwszy zachodni minister spraw zagranicznych, udał się do Budapesztu ${ }^{57}$. Dla porównania, w latach 60. stosunki Austrii z Rumunią i Bułgarią rozwijały się bez napięć. Stabilna sytuacja polityczna za żelazną kurtyną była zachętą do planowania i realizowania wizyt dwustronnych, za którymi szły umowy gospodarcze i poprawa wymiany handlowej z państwami komunistycznymi ${ }^{58}$.

\footnotetext{
${ }^{54} \mathrm{Na}$ temat austriackiej polityki integracyjnej B. Kreisky, Die Zeit in der wir leben. Betrachtungen zur internationalen Politik, Wien 1978, s. 73-102, 107-129.

${ }^{55}$ Stiftung Bruno Kreisky Archiv [dalej: StBKA], Länderboxen Polen, Box 5, „Besuch Außenminister Rapacki 1961. Protokoll”: Protokolle der Besprechungen am 9. März 1961 in Wien, s. 48.

${ }^{56}$ B. Kreisky, Im Strom. Erfahrungen lines Europäers, Wien 1988, s. 220.

${ }^{57}$ A. Gémes, Austrian-Hungarian relations, 1945-1989, [w:] Peaceful Coexistance or Iron Curtain? Austria, Neutrality and Eastern Europe in the Cold War and Détente, 1955-1989, ed. W. Mueller, Wien 2009, s. 310-335.

${ }^{58}$ B. Kreisky, Politik braucht Visionen, Aufsatze, Reden und Interviews zu aktuellen weltpolitischen Fragen mit einem Vorwort von Walter Jens, Bonn 1982, s. 107-150. Polska była pierwszym krajem wschodnim, jaki odwiedził minister Kreisky. W następnych tygodniach udał się do Jugo-
} 


\section{Wartość ekonomiczna współpracy z krajami wschodnimi}

Obszar wschodni - Oststaaten był dla Austriaków bardziej atrakcyjny w okresie międzywojennym. Wysyłano tam wówczas $28-35 \%$ produkcji. Po 1945 roku wskaźniki wymiany ze Wschodem zaczęły spadać do 9\% w 1988 roku, co wiązało się z większym zainteresowaniem rynkami EFTA - do 1950 roku kierowano tam $46 \%$ produkcji, a także obszarem Wspólnoty Europejskiej - 64\% produkcji w roku 1988. Podobnie było z importem. W latach 1950-1992 import z państw wschodnich dotyczył od 6 do 13\% całości sprowadzanych do Austrii produktów ${ }^{59}$. Przez państwa Europy Środkowej Wiedeń był postrzegany jako ważny partner gospodarczy. Oceniając politykę zagraniczną austriackich socjalistów w Europie Środkowej, zwracano uwagę na otwarcie II Republiki na problemy międzynarodowe $i$ „nieszablonowe” rozwiązania. U schyłku lat 60. państwa wschodnie zintensyfikowały działania mające na celu podpisanie umów handlowych mogących bądź to uzupełnić deficyt towarów, bądź zapewnić dostęp do nowych technologii. Związek Radziecki nie był w stanie zapewnić wszystkim państwom satelickim wsparcia gospodarczego lub też często traktował dystrybucję dóbr czy surowców jako zapłatę za polityczną uległość na forum międzynarodowym. Dodatkowym utrudnieniem realiów ekonomicznych i decyzyjności na poziomie centralnym była działalność RWPG. Struktura ta narzucała ograniczenia w podejmowaniu niezależnych decyzji gospodarczych, chociażby przez nakładanie na poszczególne kraje zobowiązań w ramach planów wieloletnich ${ }^{60}$.

Polityka inwestycyjna Austrii oparta była na stworzeniu warunków politycznych i prawnych do budowy odpowiedniej infrastruktury zapewniającej rozwój i wzajemne korzyści. Uzyskane przez Polskę w 1967 roku członkostwo w GATT (General Agreement on Tariffs and Trade - Układ Ogólny w sprawie Ceł i Handlu) umożliwiło wprowadzenie do tekstu umowy z 1968 roku klauzuli najwyższego uprzywilejowania w wymianie towarowej między Austrią i Polską. Warunki członkostwa nie były dla Polski łatwe. Podpisane zobowiązania wskazywały na systematyczny coroczny wzrost eksportu towarów z krajów GATT, tymczasem utrudnieniem był brak dewiz i ograniczenia dla eksportu polskich produktów.

Pierwsze rozmowy na temat liberalizacji handlu i specyfikacji produktów pochodzących z Europy Środkowej podjęto w latach 60. XX wieku. W latach 1972-1973 rozpoczęto również rozmowy na temat umów kredytowych. Polska

sławii (16-20.03.1960), potem do Rumunii (24.07.1963 i 29.10 - 1.11.1964) i Bułgarii (9-13.07.1965). Do Pragi Kreisky, jako minister spraw zagranicznych, nie pojechał. Natomiast w latach 19591966 przebywał dwukrotnie z wizytą państwową w ZSRR (5-14.10.1959 i 26.06 - 4.07.1962).

${ }^{59}$ D. Stiefel, Österreich und die planwirtschaftlichen Länder, [w:] „Zarte Bande”. Österreich und die europäischen planwirtschaftlichen Länder. „Delicate Relationship”. Austria and Europe's Planned Economies, Hrsg. G. Enderle-Burcel, D. Stiefel, A. Teichova, Wien 2006, s. 35.

${ }^{60}$ R. Skobelski, PRL w Radzie Wzajemnej Pomocy Gospodarczej w latach 1956-1970, „Kwartalnik Historyczny" 2007, nr 3, s. 49-90. 
miała je otrzymać na rozwój infrastruktury przemysłu wydobywczego i chemicznego ${ }^{61}$. Kredyty austriackie wiązały się, z jednej strony, z potrzebą pozyskiwania funduszy z kilku źródeł i poszukiwania najbardziej korzystnych rozwiązań, z drugiej zaś - z wprowadzenia w Polsce zasad nowej polityki kredytowej $^{62}$. Rok później podpisano jedno z ważniejszych porozumień handlowych po drugiej wojnie światowej - Umowę o dostawach energii elektrycznej z Polski do Austrii oraz o imporcie do Polski dóbr inwestycyjnych i urządzeń na warunkach kredytowych ${ }^{63}$.

Kredyty udzielane przez Austrię dzieliły się na kilka podstawowych grup. Najważniejsze z nich służyły finansowaniu inwestycji. Kolejne sumy były przeznaczane na zakup surowców i półproduktów. Trzecią grupę stanowiły kredyty na artykuły konsumpcyjne ${ }^{64}$. Do końca 1978 roku, przy całkowitej kwocie kredytu 23,5 mld szylingów, 3 mld przeznaczono na zakup dóbr inwestycyjnych w Austrii, 4,7 mld na zakup wyrobów stalowych, 4,3 mld na licencje i kooperację z przedsiębiorstwami austriackimi, 1,1 mld na zakup surowców chemicznych, 6,5 mld na zakup w ramach planu pięcioletniego, $360 \mathrm{mln}$ na artykuły rolno-spożywcze. W tym czasie do dyspozycji Banku Handlowego pozostawała kwota 1,6 mld szylingów ${ }^{65}$.

Jedną z pierwszych ważniejszych inwestycji była współpraca podjęta w 1973 roku z koncernem Steyr-Daimler, dotycząca produkcji maszyn budowlanych, wywrotek i ciągników siodłowych. Dwa lata później współpraca została rozwinięta dodatkową umową z firmą „Polmot”. Chodziło o budowę ciężarówek o ładowności od 18 do 32 ton, wyposażonych w silniki o mocy $450 \mathrm{KM}$. Na realizację tej umowy bank austriacki udzielił wówczas kredytu ${ }^{66}$. W 1975 roku doszło też do podpisania ważnej umowy dotyczącej współpracy na rynkach trzecich. Polskie przedsiębiorstwo „Polimex-Cekop” i austriackie „Voest Alpine" zdecydowały o budowie fabryki melaminy, podejmując przy tym współpracę z koncernem Linz AG. Zachęciło to inne polskie przedsiębiorstwa do podpisywania podobnych umów w kolejnych latach ${ }^{67}$.

${ }^{61}$ StBKA, Länderbox Polen, Box 5, Aide Memoire (XI 1973).

${ }^{62}$ J. Gajdek, Der mittelbare Nachbar. Ósterreichvorstellungen in Polen 1970-1995, [w:] Mit anderen Augen gesehen. Internationale Perzeptionen Österreichs 1955-1990 (Österreichische Nationalgeschichte nach 1945 2), Hrsg. O. Rathkolb, O.M. Maschke, S.A. Lütgenau, Wien-Köln-Weimar 2002, s. 661.

${ }^{63}$ Porozumienie z 2 października 1974 roku weszło w życie tego samego dnia. W latach 19731974 podpisano łącznie siedem traktatów dwustronnych, z czego większość obowiązuje do dziś. StBKA, Länderbox Polen, Box 4, Offizieller Besuch des Präsidenten des Ministerrates der VR Polen, Piotr Faroszewicz, in Osterreich, 30.09.-3.10.1974.

${ }^{64}$ AMSZ D. IV: Austria, z. 1/84, w. 3. Pismo B. Kulskiego z 21 VIII 1978 roku.

${ }^{65}$ Ibidem, s. 4. Zdaniem chargé d'affaires ambasady w Wiedniu B. Kulskiego, do końca 1978 roku Polska spłaciła 9438 mld szylingów.

${ }^{66} \mathrm{~A}$. Wieczorkiewicz, Kooperacja przemystowa Polski z rozwiniętymi krajami kapitalistycznymi, Warszawa 1980, s. 126-127.

${ }^{67}$ AMSZ D. IV: Austria, z. 1/84, w. 3. Podstawowe elementy działalności B. Kreisky'ego i roli Socjalistycznej Partii Austrii w Międzynarodówce Socjalistycznej, z II 1978 roku, s. 10. 
Potencjał Polski na tle pozostałych państw Europy Środkowej oceniano wysoko i spodziewano się, że zmiany w pozostałych krajach bratnich będą przebiegały podobnie ${ }^{68}$. Władze austriackie zwracały również uwagę na fakt częstych wizyt polskich przywódców we Francji i Szwecji, co skutkowało przywilejami gospodarczymi, jakie otrzymały państwa zachodnie i kredytami dla Polski ${ }^{69}$. Niestety, tak prowadzona aktywna polityka wobec Zachodu nie była pozytywnie oceniana przez władze moskiewskie. Pierwsze oznaki „przeinwestowania” polskiej gospodarki dały się odczuć już w 1976 roku. Gremium kierownicze w Warszawie planowało podnieść ceny żywności, przed czym przestrzegał podczas osobistych spotkań Leonid Breżniew, grożąc zamrożeniem części dostaw surowców i zboża ${ }^{70}$. Doszło do nich w następnych latach.

Narastające w relacjach USA-ZSRR napięcie ograniczało aktywność krajów socjalistycznych nie tylko politycznie. W latach 1977-1978 rozwijano polsko-austriacką współpracę podczas spotkań nieoficjalnych, których efektem była wymiana surowców i energii za cenę kolejnych kredytów. W dniach od 16 do 17 września 1977 roku premier Piotr Jaroszewicz udał się z nieoficjalną wizytą do Wiednia ${ }^{71}$. Omawiano wówczas transfer energii elektrycznej, budowę instalacji do produkcji koksu naftowego, współpracę z koncernem Steyr-Daimler-Puch, a także zatrudnienie polskich specjalistów w austriackich przedsiębiorstwach ${ }^{72}$. Wiele uwagi poświęcono wówczas potencjalnej współpracy z Czechosłowacją, która była krajem tranzytowym. Rozmowy prowadzono w październiku i listopadzie 1977 roku. Strona czechosłowacka domagała się rozmów trójstronnych i większych korzyści z tytułu transmisji polskich dóbr. Władze austriackie starały się być pośrednikiem i unikały spotkań w większym gronie. W sytuacji, kiedy napotykano przeszkody podczas negocjacji, kierowano temat pod obrady KBWE lub stosowano inne formy nacisku ${ }^{73}$. W korespondencji Urzędu Kanclerskiego odnajdujemy różne rozwiązania dotyczące współpracy trójstronnej. Sugerowano, aby podczas rozmów z Pragą unikać wrażenia, że pomoc czechosłowacka jest nieodzowna, ale że Wiedeń rozważa alternatywne drogi przesyłania polskiej energii przez ZSRR i Węgry ${ }^{74}$.

Austria dążyła do zwiększenia importu polskiej energii i surowców, dyskutowano też na temat powstającej infrastruktury i dodatkowych projektów.

\footnotetext{
${ }^{68}$ StBKA, Länderbox Polen, Box 4, Liefer und Kooperationsvereinbarungen mit Polen, 1975.

${ }^{69}$ Ibidem, Länderbox Polen, Box 4, Besuch des Vorsitzenden des Staatsrates der VR Polen Prof. Dr. Henryk Jablonski in Österreich, 26.30. April 1976.

${ }^{70}$ A. Skrzypek, Dyplomacja polska, [w:] Historia dyplomacji polskiej, t. VI, s. 749.

${ }^{71}$ StBKA, Länderbox Polen, Box 3, Informationsmappe betr. den Besuch des polnischen MP Jaroszewicz in Österreich, September 1977.

${ }^{72}$ Ibidem, Länderbox Polen, Box 4, Informationsmappe betr. den inoffiziellen Besuch des Herrn BK in Polen, 16.-19.9.1976.

${ }^{73}$ Ibidem, Länderbox Polen, Box 3, Information für Herrn Bundeskanzler (1979).

${ }^{74}$ Ibidem, Länderbox Polen, Box 3, Dr. Walter Fremuth - BKA betr. Finanzierung von 300 Mio.\$ an VR Polen, Kohlenliefervertrag, 10.12.1979.
} 
W protokole rozmów pomiędzy premierem Piotrem Jaroszewiczem i kanclerzem Bruno Kreiskym z 16 września 1977 roku wymieniono czterech przyszłych inwestorów i przewidywane dodatkowe plany: Voest Alpine (7 projektów), Klin Union (2), Verenigte Metallwerke (1), Waagner Brio (1) ${ }^{75}$.

$\mathrm{W}$ dokumencie przygotowanym dla potrzeb grup roboczych czytamy, że w gronie państw wschodnich na szczególną uwagę zasługiwały ZSRR i Polska. Te kraje produkowały systematycznie od początku lat 70 . więcej energii, niż były w stanie wykorzystać ${ }^{76}$. Zdaniem ekspertów, poza samą produkcją, która systematycznie wzrastała, należało zwrócić uwagę na bogate złoża. Państwa wschodnie nie poszukiwały alternatywy w pozyskiwaniu energii, w niewielkim stopniu wykorzystywały również energię jądrową. Strona sowiecka wyraźnie sprzeciwiała się wówczas polskim projektom, w których bazą miały być surowce pochodzące ze Związku Sowieckiego. Należy dodać, że w tym czasie ich cena wyraźnie wzrosła ${ }^{77}$.

Nie znając szczegółów realizacji tej zmiany, władze austriackie próbowały określić tendencje na nadchodzące lata. Inwestycje, jakie realizowano w Polsce, nie przyczyniły się do poprawy sytuacji, gdyż napotykały niedoinwestowaną gospodarkę. Dysproporcje w rozwoju poszczególnych gałęzi przemysłu czy brak możliwości eksportu towarów atrakcyjnych, za które Polska mogłaby otrzymywać dewizy potrzebne do spłaty długów, przyspieszyły kryzys ${ }^{78}$. Aby sprostać wymaganiom kredytowym, zaciągano nowe pożyczki, często pod presją inwestorów, którzy grożąc wycofaniem się z umów, domagali się zaciągania kolejnych zobowiązań. Następstwem wielkiej fali inwestycyjnej z pierwszej połowy dekady był więc nie tyle wzrost produkcji eksportowej, ile ograniczenia importowe w drugiej pięciolatce ${ }^{79}$. Przeprowadzono je po 1976 roku kosztem jakości produkowanych na eksport produktów i wydłużenia procesu inwestycyjnego. Rozdział środków na modernizację konsekwentnie pomijał gałęzie produkujące i świadczące usługi dla ludności (handel, rolnictwo, gospodarkę komunalną i mieszkaniową), co wywołało niepokoje społeczne.

Pod koniec lat 70. władze PRL usiłowały spłacać wszystkie długi, zyskując opinię solidnego dłużnika. Reformy nie przyniosły jednak istotnych zmian systemowych w gospodarce, w szczególności w handlu zagranicznym i bankowej obsłudze transakcji zagranicznych. Brak zmian był zjawiskiem typowym dla całego bloku radzieckiego w tym okresie, uważano je za niebezpieczne politycznie. Wyjątek stanowiły Węgry, które od połowy lat 70. prowadziły akty-

\footnotetext{
${ }^{75}$ Ibidem, Länderbox Polen Box 3, Informationsmappe betr. den Besuch des polnischen MP Jaroszewicz in Österreich, September 1977.

${ }^{76}$ Ibidem, Länderbox Polen Box 3, The energy situation between East and West.

${ }^{77}$ A. Skrzypek, Dyplomacja polska..., s. 756.

${ }^{78}$ L. Jasiński, op. cit., s. 260.

${ }^{79}$ A. Ząbkowicz, Koncepcja zagranicznej polityki kredytowej w Polsce w latach 1971-1980, Wrocław 1992, s. 35.
} 
wną politykę ułatwiającą inwestycje nad Dunajem ${ }^{80}$. W świetle niektórych ocen jedna trzecia zadłużenia zagranicznego powstała na skutek nieumiejętnych zakupów licencji. Nadmierny import rozwiązań technicznych oddziaływał ujemnie na pracę krajowych ośrodków badawczych i wdrożeniowych ${ }^{81}$.

Rok 1978 kończył okres względnej pomyślności gospodarczej. Z badań przeprowadzonych przez Leszka Jasińskiego wynika, że ogromna część środków dewizowych została wydana w sposób nieuzasadniony. Wynikało to $\mathrm{z}$ wielu zaniedbań, braku wiedzy i możliwości, nieuczciwości i braku planowania ${ }^{82}$. Trudno dziś ustalić skalę nadużyć z uwagi na liczne działania cenzury w obszarze, który dotyczył wymiany handlowej zarówno z krajami zachodnimi, jak i RWPG ${ }^{83}$.

Ze względu na prognozy gospodarcze dotyczące wymiany gospodarczej, wynikające $\mathrm{z}$ analizy wydolności polskiego sektora energetycznego, strona austriacka zastanawiała się nad poszukiwaniem alternatywy. Sytuacja, w której Polska przestałaby wypełniać zobowiązania dotyczące eksportu energii, była dla Austrii niebezpieczna, stąd poszukiwanie dodatkowych zabezpieczeń ${ }^{84}$. W pierwszej kolejności próbowano pomóc w spłacie długów, jakie Warszawa zaciągnęła w ostatnich latach. Od 6 do 11 listopada 1979 roku w Wiedniu obradowała komisja mieszana ds. współpracy gospodarczej, przemysłowej i naukowo-technicznej ${ }^{85}$. Główne zadanie, jakie przed nią postawiono dotyczyło usprawnienia wymiany towarowej. W trakcie spotkania doszło do rozmowy pomiędzy ministrem Olszewskim i kanclerzem Kreiskym. Polski minister został przyjęty przez kanclerza 7 listopada. Kreisky zasugerował możliwość współpracy nad rozbudowanym projektem dotyczącym pozyskiwania energii. O przebiegu rozmowy donosił do MSZ ambasador Andrzej Jedynak, prosząc o natychmiastową reakcję. Austriacy proponowali budowę elektrowni atomowej w Polsce. Finansowanie inwestycji miało pochodzić z Austrii i RFN, a tranzyt miał przebiegać przez Czechosłowację lub Węgry. Kanclerz uzasadniał swój projekt koniecznością rozwoju współpracy energetycznej Wschód-Zachód. Jednocześnie starano się uniknąc ataków społecznych w związku z budową tego typu obiektu na terenie Austrii ${ }^{86}$.

${ }^{80}$ A. Gémes, op. cit., s. 333.

${ }^{81}$ R. Rapacki, System gospodarczy a import techniki w Polsce, „Handel Zagraniczny” 1989, nr 45 , s. 48.

${ }^{82}$ L. Jasiński, op. cit., s. 274.

${ }^{83}$ T. Strzyżewski, Czarna księga cenzury PRL, Londyn 1977, s. 31-39.

${ }^{84}$ Analizowano nie tylko zasoby, jakimi Polska dysponowała, ale także prognozy dotyczące poszukiwania nowych złóż. W korespondencji pomiędzy Urzędem Kanclerskim i szefami grup roboczych, Walterem Neudoerferem i Walterem Fremuthem, wielokrotnie pojawiał się temat opłacalności polskich surowców i poniesionych nakładów inwestycyjnych. StBKA, Länderbox Polen, Box 3, Information, 21.11.1979.

${ }^{85}$ Efekty prac grupy roboczej rozbudowała komisja mieszana, pracująca w Wiedniu od 20 do 24 listopada. Wyniki obrad podano bezpośrednio na ręce ministra Josefa Staribachera, a ten przywiózł je na spotkanie do Polski. AMSZ, D. IV: Austria, z. 4/84, w. 3, t. 1.

${ }^{86}$ AMSZ D. IV: Austria, z. 4/84, w. 3, t. 1, Szyfrogram nr 1977/IV z 8 XI 1979. 


\section{Podsumowanie}

Nazywając ogół stosunków z państwami ze wschodniej części Europy polityką sąsiedztwa, doprowadzono do stworzenia nowych warunków i nowych wartości w tych relacjach i przeniesiono je na grunt partnerski. Politycy austriaccy byli świadomi pewnych przemian związanych z dookreślaniem tożsamości obszaru Europy Środkowej. Dookreślenie owo stanowiło proces emancypacji społeczeństw tego regionu, które odzyskiwały głos i coraz wyraźniej promowały własną narrację wspólnej historii i polityki ${ }^{87}$.

Zarówno rząd austriacki, reprezentowany przez ministra Kreisky'ego, jak i Willy Brandt byli kontrolowani przez administrację Richarda Nixona, a zwłaszcza sekretarza stanu - Henry’ego Kissingera, aby w swojej kooperacji z państwami zza żelaznej kurtyny nie posunęli się zbyt daleko ${ }^{88}$. Pisząc o polityce wschodniej, polscy badacze zwracają uwagę na podstawy, jakie stworzyli dla tych stosunków dwaj kanclerze: Konrad Adenauer i Kurt Georg Kiesinger. Wszyscy byli jednak zgodni, że Niemcy zawdzięczały otwarcie na Wschód Willy'emu Brandtowi ${ }^{89}$. W obecnych badaniach austriackich zwraca się uwagę na fakt, że to dyplomaci z Wiednia jako pierwsi rozpoznali potrzebę współpracy z sąsiadami na wschodzie.

Efektem zmian było stworzenie stosunków multilateralnych opartych na ułatwieniach płatniczych i celnych, a co za tym idzie, stworzenie wspólnych organizacji tych państw. Integracja gospodarcza w postaci EWG zakładała utworzenie „ponadpaństwowej wspólnoty”. Austria nie przystąpiła do niej, choć łączyły ją z tym obszarem ponadpięćdziesięcioprocentowe obroty handlowe. Była to cena za zachowanie neutralności. W ramach alternatywy wybrano porozumienie EFTA - obroty z jej państwami sięgały $13 \%$.

Austriackie inwestycje i wsparcie przemysłu maszynowego, a także motoryzacyjnego przyniosły w 1979 roku wzrost importu z Austrii o 800\% w porównaniu z wartościami z 1970 roku. Wartość eksportu rosła powoli, ale systematycznie do $400 \%$ w porównaniu z 1970 rokiem i dotyczyła głównie surowców energetycznych ${ }^{90}$. Jeśli porównamy te wskaźniki z podziałem całego eksportu

\footnotetext{
${ }^{87}$ W. Parafianowicz-Vertun, op. cit., s. 61.

${ }^{88}$ O. Rathkolb, „Washington ruft Wien”. U.S.-Grossmachtpolitik gegenüber Österreich 1952-1962, Wien-Köln-Weimar 1994, s. 211.

${ }^{89}$ Wśród polskich badań dotyczących początków polityki wschodniej Niemiec wymienić można choćby: W. Jarząbek, Polska Rzeczpospolita Ludowa wobec polityki wschodniej Republiki Federalnej Niemiec w latach 1966-1976. Wymiar dwustronny i międzynarodowy, Warszawa 2011, s. 396-413; B. Koszel, Niemcy wobec Europy Środkowej i Poludniowo-Wschodniej w drugiej połowie XIX $i$ w XX w. (do 1989 r.). Koncepcje dziatań i próby organizacji polityczno-gospodarczej, „Przegląd Zachodni” 1997, nr 1, s. 93-116; R. Łoś, Wschodnia polityka kanclerza K. Adenauera, Łódź 2003, s. 50-62; M. Ratajczak, Droga do uznania granicy na Odrze i Nysie Łużyckiej: aspekty prawne, „Acta Uniwersitatis Wratislawiensis. Niemcoznawstwo” 1998, nr 8, s. 157-181.

${ }^{90} \mathrm{P}$. Franaszek, Die Handelsbeziehungen zwischen der Volksrepublik Polen und Österreich in der Zeit von 1945-1989, [w:] „Zarte Bande”..., s. 192.
} 
austriackiego, to udział państw wschodnich, choć bardzo niewielki, pozwalał na widoczny rozwój tej części Europy.

Najbardziej uprzemysłowione kraje, Czechosłowacja i Węgry, korzystały zaledwie po $1 \%$ z dóbr wysyłanych z Austrii, udział Polski był jeszcze mniejszy $^{91}$. Wartość pieniężna importu towarów austriackich wyniosła w 1971 roku 66 mln dolarów ${ }^{92}$. Warto jednak zwrócić uwagę, że Austria była jednym z wielu państw, które inwestowały wówczas w państwach komunistycznych. Dając początek nowym gałęziom produkcji, wspierała zmiany w strukturze gospodarczej Polski i pozostałych krajów Europy Środkowej.

Zniesiono system kontyngentowania i zliberalizowano wzajemną wymianę towarową. Potwierdzono przyjęcie zasady najwyższego uprzywilejowania, zgodnej z artykułem I GATT. Określono warunki swobodnego przepływu towarów i finansów ${ }^{93}$. Podstawą ożywionej współpracy gospodarczej były wieloletnie umowy handlowe. W latach 1972-1976 wprowadzono rozrachunek $\mathrm{w}$ walucie wymienialnej zamiast funkcjonującego dotychczas clearingowego systemu wzajemnych rozliczeń. Anulowano Układ płatniczy z 1954 roku i Umowę handlową z 1967 roku. Umowa miała obowiązywać do 31 grudnia 1976 roku. Zaopatrzono ją w Protokół dodatkowy, uzupełniający wskaźniki wzajemnej wymiany towarowej. Rząd austriacki przewidział potrzebę silnej kooperacji z państwami wschodnimi w kontekście rozwijającego się kryzysu energetycznego.

Uwagi dotyczące najważniejszych regulacji prawnych związanych z wymianą handlową wskazują na kluczową rolę kwestii kredytów udzielanych Polsce. To one były głównym przedmiotem żmudnych negocjacji w miarę postępującego kryzysu i nerwowej sytuacji w stosunkach Polski z Zachodem. Przyspieszenie inwestycyjne, jakie zapowiadano w latach 70., miało wynikać nie z rekonstrukcji i modernizacji istniejących zakładów produkcyjnych, lecz produkcji nowych. Nowe zjawiska w gospodarce światowej interpretowano jako sprzyjające Polsce. Inflacja walut, a przede wszystkim deprecjacja dolara amerykańskiego (dwukrotna dewaluacja z grudnia 1971 i lutego 1973 roku) zachęcały do przyjęcia przez polskie władze „filozofii zadłużania się”. Wraz z narastaniem kryzysu naftowego międzynarodowy system walutowy został zasilony ogromną liczbą „petrodolarów”. Nie martwiono się o warunki podpisywanych kredytów w sytuacji, gdy instytucje finansowe poszukiwały chętnych na pieniądze zalegające w bankach ${ }^{94}$. Zdaniem przewodniczącego Komisji Planowania przy Radzie Ministrów, Mieczysława Jagielskiego, inflacja w krajach zachodnich doprowadziła do obniżenia kosztów kredytów zagranicznych.

${ }^{91}$ D. Stiefel, op. cit., s. 35.

${ }^{92}$ Główny Urząd Statystyczny, Austria-Polska - wybrane dane porównawcze, Warszawa 1972, s. 76.

${ }^{93}$ J. Sikorski, Przyszłość polsko-austriackich stosunków gospodarczych, „Sprawy Międzynarodowe" 1973, nr 9, s. 104-113.

${ }^{94}$ S. Długosz, fak zadtużytem PRL, Warszawa 1995, s. 43. 
Było to błędne założenie, gdyż przyspieszony wzrost inflacji i różnokierunkowe zmiany kursów walut i stóp procentowych w poszczególnych krajach przerzucał ryzyko związane ze wzrostem inflacji na kredytobiorcę. Błędy w kalkulacjach wynikały też z rozliczania bilansów płatniczych w cenach bieżących. Doszło do sytuacji, w której już w roku 1975 zostały przekroczone wskaźniki uznawane powszechnie za dopuszczalną bieżącą granicę zadłużenia: 1) przekroczenie dwudziestoprocentowego wskaźnika obciążenia eksportu obsługą kredytu zagranicznego; 2) wartość zadłużenia w krajach kapitalistycznych była prawie dwukrotnie wyższa od rocznych wpływów dewizowych za eksport do tych państw, a nie powinna przekraczać wartości 1:195. Te niekorzystne zjawiska nasiliły się w drugiej połowie lat 70 .

Polska wkroczyła w lata 70. niemal bez długów, natomiast kryzysy naftowe z 1973 i 1979 roku nie dotknęły Austrii, a nawet - ze względu na specyficzne relacje z państwami arabskimi - wzmocniły jąa ${ }^{96}$ Państwa zachodnie, bazujące na doświadczeniach przezwyciężania inflacji monetaryzmem, czyli kosztem przejściowego pogorszenia koniunktury i wzrostu bezrobocia, chętnie gromadziły w bankach środki zarobione przez eksporterów paliw. Aby zarobić na oprocentowanie dużej liczby nieoczekiwanych depozytów, masowo udzielały kredytów, licząc na to, że koniunktura poprawi się, a inflacja korzystna dla dłużników będzie stała. W wyniku pogłębienia monetaryzmu na początku lat 80 . waluty, w których dłużnicy byli zadłużeni, przestały ulegać dalszej deprecjacji, a nawet zaczęły się wzmacniać. W tej sytuacji długi stały się niemożliwe do spłacenia. Polska należała wówczas do grona państw, które z wielomiliardowym zadłużeniem eksportowały kapitał do krajów bogatych, napędzając tzw. kryzys zadłużeniowy ${ }^{97}$.

Problemy z obsługą długów zagranicznych pojawiły się już w 1980 roku, kiedy znacznie skurczyły się możliwości pozyskiwania nowych kredytów. W tym roku uzyskano od USA kredyty w wysokości 8,67 mld USD, które W całości wykorzystano na spłatę rat i odsetek. W następnym roku napłynęło 5 mld USD, natomiast na obsługę zadłużenia trzeba było wydać 9,4 mld USD, przy wpływach z eksportu w wysokości 4,9 mld USD i wydatkach na import w wysokości 5,8 mld USD. Dlatego już w kwietniu 1981 roku podpisano pierwszą umowę z Klubem Paryskim o odroczeniu spłat, a w następnym roku podobną umowę podpisano z Klubem Londyńskim. Odcinało to Polskę od nowych kredytów ${ }^{98}$. Część państw będących dłużnikami zaczęła się organizować i wspólnie domagać obniżenia oprocentowania (tzw. Grupa z Cartageny z 1984 ro-

${ }^{95}$ D. Jarosz, M. Pasztor, Stosunki polsko-francuskie 1944-1980, Warszawa 2008, s. 371.

${ }^{96}$ AMSZ, D. IV: Austria, z. 43/84, w. 5, List F. Mąkosy do f. Czyrka z 5 IX 1980 r.

${ }^{97}$ W. Morawski, Petzająca katastrofa. Gospodarka polska w latach osiemdziesiatych, [w:] W przededniu wielkiej zmiany. Polska w 1988 roku, red. A. Friszke, Gdańsk 2009, s. 28.

${ }^{98}$ Ibidem, s. 32. 
ku). Polska jednak nie prowadziła takiej aktywności. Nie należała do Międzynarodowego Funduszu Walutowego, jako kraj komunistyczny traktowana była na innych warunkach, a po wprowadzeniu stanu wojennego pogrążyła się w całkowitej izolacji. Z grona państw Europy Środkowej podobną sytuację miała Rumunia ${ }^{99}$.

W kwietniu 1981 roku Polska podpisała pierwsze porozumienie dotyczące pomocy w sprawie spłaty długów w Klubie Paryskim wraz z 15 wierzycielami. W ramach nowych warunków kraje zdecydowały się na rozłożenie płatności, jednak wprowadzenie stanu wojennego i fakt, że Polska nie należała do Międzynarodowego Funduszu Walutowego całkowicie uniemożliwił dalsze negocjacje $\mathrm{e}^{100}$. Polska polityka kredytowa poniosła dotkliwą porażkę. Głównym powodem były warunki polityczne, w jakich funkcjonował nasz kraj. Polska nie należała do systemu gospodarki wolnorynkowej i podejmowanie działań, które ignorowały ten fakt musiało przynieść katastrofalne skutki. Niemożliwe było rozwiązanie polskich problemów gospodarczych i społecznych bez zasadniczych zmian dotyczących zasad funkcjonowania państwa, a te były całkowicie uzależnione od arbitralnych decyzji z Moskwy.

Po wprowadzeniu stanu wojennego w Polsce wzrosła liczba inwestycji austriackich i niemieckich na Węgrzech ${ }^{101}$. Zwiększyła się również turystyka obywateli niemieckojęzycznych do tego państwa. Dalekosiężne plany stworzenia z Rumunii państwa odgrywającego istotną rolę międzynarodową były oparte na przyspieszonej i wycieńczającej industrializacji, której ani zasoby materiałowe, ani demograficzne tego państwa nie były w stanie znieść. Naturalną konsekwencją było „odangażowanie” Wiednia z tego obszaru i przeniesienie części planów inwestycyjnych do Węgier i Czechosłowacji. Ze względu na słaby rozwój gospodarczy relacje austriacko-bułgarskie rozwijały się w latach 80 . głównie w oparciu o wymianę kulturalną placówek oświatowo-badawczych i działalności wystawienniczej ${ }^{102}$.

Warto podkreślić, że pisząc o wymianie gospodarczej Austrii z krajami wschodnimi konsekwentnie unikano w odniesieniu do tych państw terminu Ostpolitik, ani też nie formułowano tez o współpracy z blokiem. Weronika Parafianowicz-Vertun zwraca uwagę, że termin Wschód, państwa wschodnie miał złą konotację w niemieckojęzycznym dyskursie publicznym. Nazywając ogół stosunków z państwami ze wschodniej części Europy polityką sąsiedztwa doprowadzono do stworzenia nowych warunków i nowych wartości w tych relacjach i przeniesiono je na grunt partnerski. Bruno Kreisky był nie tylko świadom

\footnotetext{
${ }^{99}$ Ibidem, s. 33.

${ }^{100}$ W. Jarząbek, Polish Economic policy at the time of détente, 1966-78, „European Review of History - Revue europeénne d'histoire" 2014, Vol. 21, Issue 2, s. 305.

${ }^{101}$ A. Gémes, op. cit., s. 333.

${ }^{102}$ P. Bachmaier, Austrian-Bulgarian Cultural Relations, [w:] Peaceful Coexistance or Iron Curtain? Austria, Neutrality and Eastern Europe in the Cold War and Détente, 1955-1989, ed. W. Mueller, Wien 2009, s. 487-508, tutaj 504.
} 
pewnych wspólnych politycznych i kulturowych punktów odniesienia, jakie posiadała Austria, Polska, Czechosłowacja, Węgry i Rumunia. Miał również świadomość przemian związanych z dookreślaniem tożsamości obszaru Europy Środkowej ${ }^{103}$. Ponadto w historii dyplomacji termin Ostpolitik jest jednoznacznie kojarzony z polityką wschodnią zdefiniowaną i realizowaną przez ministra spraw zagranicznych, a później kanclerza RFN Willy’ego Brandta od 1966 roku $^{104}$.

Wiedeń do 1965 roku wyznaczył najważniejsze cele polityki sąsiedztwa i umocnił swoją pozycję w regionie. Wskazał na konieczność rozszerzania umów handlowych ze Wschodem, a także zacieśniania współpracy kulturalnej, która miała być nowym wyznacznikiem rozwoju Europy Środkowej. Można powiedzieć, że tym samym wyprzedził w relacjach z państwami wschodnimi Ostpolitik realizowaną w następnych latach przez niemieckiego kanclerza Willy'ego Brandta. Przez cały okres rozwoju polityki sąsiedztwa Austria konsekwentnie unikała nazywania polityki sąsiedztwa polityką wschodnią. Uważano, że koncepcja Ostpolitik była tożsama z dyplomacją niemiecką i zdecydowanie się od niej odcinano. Nie czyniono tego z potrzeby negacji działań niemieckich, lecz wyznaczenia własnych celów i standardów relacji z państwami komunistycznymi. Podkreślano, że nie należy ich określać blokiem wschodnim, ani też traktować jako monolitu, gdyż czyni się wówczas przysługę Moskwie.

Uważano ponadto, że określenie Ostpolitik podkreśla wschodni, gorszy charakter tego regionu, co było zgodne z tym, jak do dziejów Europy Środkowo odnosiła się historiografia niemiecka. Natomiast pojęcie polityki sąsiedztwa miało podkreślać punkty wspólne w przeszłości, polityce i kulturze krajów związanych z Wiedniem i stanowić o jego partnerskim charakterze. Choć od czasów emigracji w Szwecji Kreisky przyjaźnił się z Willym Brandtem i cenił jego dokonania w polityce zagranicznej, podkreślał rolę aktywnej polityki międzynarodowej Austrii w procesie kształtowania nowej tożsamości narodowej. W Austrii trwała wówczas ważna debata dotycząca przyszłości. Rozważano nie tylko możliwości integracji gospodarczej w ramach EWG, lecz także poszukiwano nowych kierunków rozwoju neutralnej republiki, zaznaczając jej odrębność w stosunku do Niemiec.

\section{Bibliografia}

Archiwum Ministerstwa Spraw Zagranicznych, D. IV: Austria, z. 47/77, w. 7, Notatka biograficzna 1973.

Archiwum Ministerstwa Spraw Zagranicznych, D. IV: Austria, z. 47/77, w. 7, Pilna notatka z 10 maja 1973 roku.

${ }^{103}$ B. Kreisky, Im Strom..., s. 224-235.

${ }^{104}$ H. Kissinger, Dyplomacja, Warszawa 1994, s. 633-640; W. Jarząbek, Dyplomacja polska w warunkach odprężenia (styczeń 1969 - lipiec 1975), [w:] Historia dyplomacji polskiej, t. VI, s. 662-692. 
Archiwum Ministerstwa Spraw Zagranicznych, D. IV: Austria, z. 47/77, w. 7, Pilna notatka $z 9$ lipca 1973 roku.

Archiwum Ministerstwa Spraw Zagranicznych, D. IV: Austria, z. 31/82, w. 4, Tezy do rozmów Towarzysza Premiera P. Jaroszewicza z Kanclerzem Austrii, Bruno Kreiskym podczas nieoficjalnej wizyty w Polsce $w$ dniach 16-20 września 1976 roku.

Archiwum Ministerstwa Spraw Zagranicznych, D. IV: Austria, z. 1/84, w. 3, Pismo B. Kulskiego z 21 VIII 1978 roku.

Archiwum Ministerstwa Spraw Zagranicznych, D. IV: Austria, z. 1/84, w. 3, Podstawowe elementy działalności B. Kreisky'ego i roli Socjalistycznej Partii Austrii w Międzynarodówce Socjalistycznej z II 1978 roku.

Archiwum Ministerstwa Spraw Zagranicznych, D. IV: Austria, z. 4/84, w. 3, t. 1, Szyfrogram nr 1977/IV z 8 XI 1979.

Archiwum Ministerstwa Spraw Zagranicznych, D. IV: Austria, z. 43/84, w. 5, Informacja o wynikach wizyty Prezesa Rady Ministrów Towarzysza Edwarda Babiucha w Austrii.

Archiwum Ministerstwa Spraw Zagranicznych, D. IV: Austria, z. 43/84, w. 5, List f. Makosy do f. Czyrka z 5 IX 1980 r.

Archiwum Ministerstwa Spraw Zagranicznych D. IV: Austria, z. 46/84, w. 2, Planowanie wizyty Bruno Kreisky'ego w Polsce.

Archiwum Ministerstwa Spraw Zagranicznych, D. IV: Austria, z. 8/86, w. 4, Notatka o ważniejszych aspektach stosunków polsko-austriackich.

Archiwum Ministerstwa Spraw Zagranicznych, D. IV: Austria, z. 8/86, w. 4, Sugestie do rozmowy Towarzysza Ministra S. Olszowskiego z austriackim ministrem Sz. W. Pahrem.

Archiwum Ministerstwa Spraw Zagranicznych, D. IV: Austria, z. 8/86, w. 4, Sugestie do rozmów Tow. f. Wiejacza $w$ Wiedniu.

Stiftung Bruno Kreisky Archiv, Länderbox Polen Box 3, Dr. Walter Fremuth-BKA betr. Finanzierung von 300 Mio.\$ an VR Polen, Kohlenliefervertrag, 10.12.1979.

Stiftung Bruno Kreisky Archiv, Länderbox Polen, Box 3, Information, 21.11.1979.

Stiftung Bruno Kreisky Archiv, Länderbox Polen, Box 3, Information für Herrn Bundeskanzler (1979).

Stiftung Bruno Kreisky Archiv, Länderbox Polen, Box 3, Informationsmappe betr. den Besuch des polnischen MP Jaroszewicz in Österreich, September 1977.

Stiftung Bruno Kreisky Archiv, Länderbox Polen, Box 3, The energy situation between East and West.

Stiftung Bruno Kreisky Archiv, Länderbox Polen, Box 4, Besuch des Vorsitzenden des Staatsrates der VR Polen Prof. Dr. Henryk Jablonski in Österreich, 26.-30. April 1976.

Stiftung Bruno Kreisky Archiv, Länderbox Polen, Box 4, Informationsmappe betr. den inoffiziellen Besuch des Herrn BK in Polen, 16.-19.09.1976.

Stiftung Bruno Kreisky Archiv, Länderbox Polen, Box 4, Liefer- und Kooperationsvereinbarungen mit Polen, 1975.

Stiftung Bruno Kreisky Archiv, Länderbox Polen, Box 4, Offizieller Besuch des Präsidenten des Ministerrates der VR Polen, Piotr Faroszewicz, in Österreich, 30.09.-3.10.1974.

Stiftung Bruno Kreisky Archiv, Länderbox Polen, Box 5, Aide Memoire (XI 1973).

Stiftung Bruno Kreisky Archiv, Länderboxen Polen, Box 5, „Besuch Außenminister Rapacki 1961. Protokoll”: Protokolle der Besprechungen am 9. März 1961 in Wien. 
Austria's International Position after the End of the Cold War (Contemporary Austrian Studies, vol. 22), eds G. Bischof, F. Karlhofer, New Orleans 2013.

Bachmaier P., Austrian-Bulgarian Cultural Relations, [w:] Peaceful Coexistance or Iron Curtain? Austria, Neutrality and Eastern Europe in the Cold War and Détente, 19551989, ed. W. Mueller, Wien 2009, s. 487-508.

Bodulan T., Z sympatii i wzajemnych korzyści, „Czas” 1976, nr 48, s. 21.

Brodzic T., Mosty i polityka, „Prawo i Życie” 1976, nr 46, s. 13.

Derlatka T., Obrady polsko-austriackiej komisji gospodarczej, „Trybuna Ludu” 1976, nr 228, s. 2.

Derlatka T., Pod figowym listkiem niezależności, „Trybuna Ludu” 1977, nr 44, s. 7.

Derlatka T., Polsko-austriacka wspótpraca gospodarcza, „Życie Warszawy” 1976, nr 227, s. 4.

Derlatka T., W obronie superbogatych, „Trybuna Ludu” 1977, nr 59, s. 6.

Der österreichische Staatsvertrag 1955. Internationale Strategie, rechtliche Relevanz, nationale Identität. The Austrian State Treaty. International Strategy, Legal Relevance, National Identity, eds A. Suppan, W. Mueller, G. Stourzh, Wien 2005.

Długosz S., Jak zadtużyłem PRL, Warszawa 1995.

Drecki R., Austria: czynny udziat w sprawach Europy, „Trybuna Ludu” 1973, nr 113, s. 7.

Fischer H., Die Kreisky-fahre, 1967-1983, Wien 1999.

Franaszek P., Die Handelsbeziehungen zwischen der Volksrepublik Polen und Österreich in der Zeit von 1945-1989, [w:] „Zarte Bande”. Osterreich und die europäischen planwirtschaftlichen Länder. „Delicate Relationship”. Austria and Europe's Planned Economies, Hrsg. G. Enderle-Burcel, D. Stiefel, A. Teichova, Wien 2006.

Gajdek J., Der mittelbare Nachbar. Österreichvorstellungen in Polen 1970-1995, [w:] Mit anderen Augen gesehen. Internationale Perzeptionen Österreichs 1955-1990 (Öster reichische Nationalgeschichte nach 1945 2), Hrsg. O. Rathkolb, O.M. Maschke, S.A. Lütgenau, Wien-Köln-Weimar 2002.

Gémes A., Austrian-Hungarian relations, 1945-1989, [w:] Peaceful Coexistance or Iron Curtain? Austria, Neutrality and Eastern Europe in the Cold War and Détente, 19551989, red. W. Mueller, Wien 2009, s. 310-335.

Główny Urząd Statystyczny, Austria-Polska - wybrane dane porównawcze, Warszawa 1972.

Graf M., Ruggenthaler P., Polnisch-österreichische Beziehungen im Kalten Krieg, [w:] Austria w polskim dyskursie publicznym po 1945 roku. Österreich nach 1945 im polnischen offentlichen Diskurs, red. A. Kisztelińska-Węgrzyńska, Kraków 2016.

Halecki O., Historia Europy, jej granice i podziaty, Lublin 2000.

Höll O., The Politics of Global Thinking. The International Significance of Bruno Kreisky, [w:] Bruno Kreisky. Seine Zeit und mehr. Era and Aftermath. Wissenschaftliche Begleitpublikation zur 240. Sonderausstellung des Historichen Museums der Stadt Wien 18. September bis 15. November 1998, Wien 1998, s. 105-117.

Jasiński L., Bliżej centrum czy na peryferiach? Polskie kontakty gospodarcze z zagranica w XX wieku, Warszawa 2011.

Jarosz D., Pasztor M., Stosunki polsko-francuskie 1944-1980, Warszawa 2008.

Jarząbek W., Dyplomacja polska w warunkach odprężenia (styczeń 1969 - lipiec 1975), [w:] Historia dyplomacji polskiej, t. VI, red. W. Materski, W. Michowicz, Warszawa 2010, s. 662-692. 
Jarząbek W., Polish Economic policy at the time of détente, 1966-78, „European Review of History - Revue europeénne d'histoire” 2014, Vol. 21, Issue 2.

Jarząbek W., Polska Rzeczpospolita Ludowa wobec polityki wschodniej Republiki Federalnej Niemiec w latach 1966-1976. Wymiar dwustronny i międzynarodowy, Warszawa 2011. Kanclerz Austrii Bruno Kreisky przybędzie do Polski, „Głos Robotniczy” 1973, nr 147, s. 1. Kissinger H., Dyplomacja, Warszawa 1994.

Kisztelińska-Węgrzyńska A., Bruno Kreisky. Polityka zagraniczna i dyplomacja wobec PRL (1959-1983), Łódź 2018.

Kisztelińska-Węgrzyńska A., Dziatalność dyplomacji amerykańskiej na rzecz podpisania Traktatu z Austria z maja 1955 roku, „Niemcy - Austria - Szwajcaria. Rocznik Katedry Badań Niemcoznawczych UŁ” 2007.

Kisztelińska-Węgrzyńska A., Österreich in der polnischen Diplomatie in den Fahren 1965-1968 aus der Perspektive des Aussenministeriums der VR Polen, „International Studies. Interdisciplinary Political and Cultural Journal (Österreich in der gegenwärtigen polnischen Forschung)" 2016, Vol. 18, s. 33-52.

Kisztelinska-Węgrzyńska A., Z historii dyplomacji polsko-austriackiej w latach 70. XX w. Wizyty kanclerza Austrii Bruno Kreisky'ego, „Przegląd Zachodni” 2015 nr 1, s. 139-157.

K.K. Sylwetka tygodnia, „Tygodnik Kulturalny” 1970, nr 13, s. 2.

Kosowski A., Wspótpraca gospodarcza państw Dunaju, „Świat i Polska” 1947, nr 18, s. 3.

Koszel B., Mitteleuropa rediviva? Europa Środkowa i Poludniowo-Wschodnia w polityce zjednoczonych Niemiec, Poznań 1999.

Koszel B., Niemcy wobec Europy Środkowej i Potudniowo-Wschodniej w drugiej połowie XIX i w XX w. (do 1989 r.). Koncepcje działań i próby organizacji polityczno-gospodarczej, „Przegląd Zachodni” 1997, nr 1, s. 93-116.

Kreisky B., Die Zeit in der wir leben. Betrachtungen zur internationalen Politik, Wien 1978.

Kreisky B., Dwudziestolecie traktatu państwowego, „Austria-Polska. Czasopismo Gospodarczo-Społeczne" 1975, nr 94, s. 1.

Kreisky B., Im Strom. Erfahrungen lines Europäers, Wien 1988.

Kreisky B., Neutralność nie oznacza absencji w polityce międzynarodowej. Rozm. M. Podkowiński, „Perspektywy” 1972, nr 23, s. 6-7.

Kreisky B., Politik braucht Visionen, Aufsatze, Reden und Interviews zu aktuellen weltpolitischen Fragen mit einem Vorwort von Walter Jens, Bonn 1982.

Kreisky B., Przemówienie 30 IX 1974, „Trybuna Ludu” 1974, nr 274, s. 2.

Kreisky B., Przemówienie [podczas spotkania w pałacu Rady Ministrów 25 VI 1973 roku], „Trybuna Ludu” 1973, nr 176, s. 4.

Kurczewska J., Kamiński A.Z., Przemiany instytucjonalne w Polsce. Elita politycznych nomadów, [w:] Dezercja elit. Konsolidacja ustroju politycznego w pokomunistycznej Polsce, Warszawa 2014, s. 81-106.

Luliński D., Austria i polityka odprężenia. Korespondencja $z$ Wiednia, „Trybuna Ludu” 1979, nr 117, s. 7.

Łoś R., Wschodnia polityka kanclerza K. Adenauera, Łódź 2003.

Madajczyk P., Dyplomacja polska w latach sześćdziesiątych, [w:] Historia dyplomacji polskiej, t. VI: 1944/1945-1989, red. W. Materski, W. Michowicz, Warszawa 2010, s. 584-654.

Maier Ch., Whose Mitteleuropa. Central Europa between Memory and Obsolescence, „Austrian in the New Europe. Contemporary Austrian Studies” 1993, Vol. 1, s. 8-19. 
Morawski W., Petzająca katastrofa. Gospodarka polska w latach osiemdziesiatych, [w:] W przededniu wielkiej zmiany. Polska w 1988 roku, red. A. Friszke, Gdańsk 2009.

Moszczeński J., Trudna kadencja. Po sukcesie SPÖ, „Życie Warszawy” 1975, nr 280, s. 8.

Parafianowicz-Vertun W., Europa Środkowa w tekstach i działaniach. Polskie i czeskie dyskusje, Warszawa 2016.

Pajewski J., „Mitteleuropa“. Studia z dziejów imperializmu niemieckiego $w$ dobie pierwszej wojny światowej, Poznań 1959.

Podkowiński M., Neutralność i wspótistnienie, „Perspektywy” 1973, nr 25, s. 26.

Podkowiński M., Obiad w Hofburgu [przed wizyta prezydenta Austrii w Polsce], „Perspektywy" 1975, nr 20.

Podkowiński M., Stanowczy kanclerz, „Perspektywy” 1975, nr 6, s. 8.

Podkowiński M., W stronę odprężenia, „Perspektywy” 1976, nr 49, s. 18.

Polska w stosunkach międzynarodowych 1945-1989. Wybór dokumentów, red. J. Zając, Warszawa 2005.

Ramotowski Z., Mat kanclerski. Austria po wyborach, „Życie Warszawy” 1975, nr 233, s. 5.

Rapacki R., System gospodarczy a import techniki w Polsce, „Handel Zagraniczny” 1989, nr 4-5, s. 4-8.

Ratajczak M., Droga do uznania granicy na Odrze i Nysie Łużyckiej: aspekty prawne, „Acta Uniwersitatis Wratislawiensis. Niemcoznawstwo” 1998, nr 8, s. 157-181.

Rathkolb O., Austria's „Ostpolitik” in the 1950s and 1960s., „Austrian History Yearbook” 1995, Vol. XXVI, s. 129-149.

Rathkolb O., „Europa mit der Seele suchen”. Bruno Kreiskys andere Europa-Visionen, [w:] Bruno Kreisky. Seine Zeit und mehr. Era and Aftermath. Wissenschaftliche Begleitpublikation zur 240. Sonderausstellung des Historichen Museums der Stadt Wien 18. September bis 15. November 1998, Wien 1998, s. 87-105.

Rathkolb O., „Washington ruft Wien”. U.S.-Grossmachtpolitik gegenüber Österreich 19521962, Wien-Köln-Weimar 1994.

Recepcja Ostpolitik w RFN $i$ w krajach bloku komunistycznego, red. J. Fischer, J. Holzer, Warszawa 2004.

Röhrlich E., Kreiskys Aussenpolitik. Zwischen österreichischer Identität und internationalen Programm, Zeitgeschichte im Kontext 2, Göttingen 2009.

Schriffl D., Tote Grenze oder lebendige Nachbarschaft? Osterreichisch-slowakische Beziehungen 1945-1968, Wien 2012.

Sikorski J., Przyszłość polsko-austriackich stosunków gospodarczych, „Sprawy Międzynarodowe" 1973, nr 9, s. 104-113.

Skobelski R., PRL w Radzie Wzajemnej Pomocy Gospodarczej w latach 1956-1970, „Kwartalnik Historyczny" 2007, nr 3, s. 49-90.

Skrzypek A., Dyplomacja polska, [w:] Historia dyplomacji polskiej, t. VI: 1944/1945-1989, red. W. Materski, W. Michowicz, Warszawa 2010, s. 584-654.

Skrzypek A., Dyplomatyczne dzieje PRL w latach 1956-1989, Warszawa 2010.

Stairbacher J., Austriacko-polskie stosunki gospodarcze, „Austria-Polska. Czasopismo Społeczno-Kulturalne" 1973, s. 13.

Staribacher J., Perspektywy wspótpracy gospodarczej z Polska, „Przegląd Organizacji” 1976, nr 10, s. 410.

Strzyżewski T., Czarna księga cenzury PRL, Londyn 1977. 
Tycner J., Ery Kreisky'ego ciag dalszy, „Prawo i Życie” 1979, nr 21, s. 13.

Urbaniak J., Austriacy oczekuja szefa polskiego rządu, „Trybuna Ludu”1965, nr 260, s. 1. W. Brandt, B. Kreisky, O. Palme, Briefe und Geschpräche. 1972-1975, Frankfurt am Main (rec. R. Kumf), „Problemy Pokoju i Socjalizmu” 1980, nr 2, s. 145-149.

Wieczorkiewicz A., Kooperacja przemysłowa Polski z rozwiniętymi krajami kapitalistycznymi, Warszawa 1980.

Ząbkowicz A., Koncepcja zagranicznej polityki kredytowej w Polsce w latach 1971-1980, Wrocław 1992. 